\title{
Article
}

http://dx.doi.org/10.11646/phytotaxa.206.1.9

\section{Intraspecific variation of insertion/length of stamens in homostylous flowers of a new species and three other species of Borreria: an unusual case in Rubiaceae ${ }^{\#}$}

\author{
SANDRA V. SOBRADO ${ }^{1, *}$ \& ELSA L. CABRAL ${ }^{1}$ \\ ${ }^{1}$ Instituto de Botánica del Nordeste (CONICET-UNNE); Facultad de Ciencias Exactas y Naturales y Agrimensura, Universidad Nacio- \\ nal del Nordeste (FaCENA-UNNE), C.P. 3400, Corrientes, Argentina. \\ *Author for Correspondence: sobradosandra@gmail.com
}

"In: Delprete, P.G. \& Dessein, S. (Editors), Festschrift volume dedicated to Timothy Motley (1965-2013). Phytotaxa 206: 1-132. (2015)

\begin{abstract}
Four species of Borreria subsection Latifoliae (Rubiaceae) present intrafloral variations in the insertion/length of stamens in homostylous flowers. Borreria heteranthera is described and illustrated as new species from the state of Pará, Brazil. The emended descriptions of Borreria hispida, B. semiamplexicaule and B. xanthophylla, with details on stamens morphology and insertion, are provided. The inclusion of B. xanthophylla in the subsection Latifoliae is proposed. Staminal arrangement, pollen grains and seed morphology of the four species are compared. A comparative table with ecological, palynological, and morphological features of each species is provided. In addition, Borreria semiamplexicaule is mentioned as a new record for the state of Mato Grosso, Brazil, and the lectotype of B. hispida is here designated.
\end{abstract}

Key words: Borreria subsect. Latifoliae, Borreria heteranthera, Borreria hispida, Borreria semiamplexicaule, Borreria xanthophylla, Brazil, French Guiana, stamen organization, pollen grains, seed morphology, Spermacoce, Spermacoceae

\section{Introduction}

Borreria Meyer (1818: 79) belongs to tribe Spermacoceae, Rubiaceae. About 100 species of this Neotropical genus are distributed in the Americas, ranging from southern United States to southern Uruguay and central Argentina. Brazil is the country with the highest diversity, where ca. 77 species are found (Bacigalupo \& Cabral 2007; Cabral \& Salas 2013).

In the last decades, the taxonomic delimitation of Borreria and its relative Spermacoce Linnaeus (1753: 102) has been debated. This debate is due to morphological variation, incomplete understanding of the group, and divergent taxonomic views. Some authors consider the two taxa as separate genera based on morphological characters (Steyermark 1972; Bacigalupo \& Cabral 1996, 2007; Bacigalupo et al. 2010; Cabral et al. 2010, 2011, 2012a, 2012b; Miguel \& Cabral 2013; Salas et al. 2011). These authors circumscribe Spermacoce s.str. by having relatively small flowers arranged in pseudoaxillary glomerules, corolla lobes internally pilose, stamens sessile, style short, all included, and indehiscent capsules or capsules with only one dehiscent valve. These authors grouped ca. 10 American species with these features (Salas et al. unpubl. data) in the genus Spermacoce. In contrast, they consider Borreria as possessing relatively large flowers [except species that belong to Borreria section Pseudodiodia Hassler (1915: 166-167), which are under study (Salas et al. unpubl. data)], arranged in axillary and spherical glomerules, corolla lobes mostly glabrous or glabrescent, stamens with well-developed filaments, style long and exserted, and dehiscent capsules with both mericarps dehiscing septicidally or with indehiscent mericarps. According to these authors, while Spermacoce s.str. has zonocolporate pollen grains with long ectocolpi surrounded by spinules and endoapertures forming an endocingulum (Type 1 sensu Pire 1996), Borreria has several pollen types and is an eurypalynous genus (Pire 1996). In contrast, other authors treated Borreria as synonymous with Spermacoce [In the Paleotropics: Verdcourt (1976), Sivarajan et al. (1987), Dessein (2003), Dessein et al. (2003a, 2003b) and Harwood \& Dessein (2005); in the Neotropics: Adams in Burger \& Taylor (1993), Adams \& Taylor (2012) Delprete (2007, 2010), Delprete et al. (2005) and Delprete \& Cortés (2006)].

Recent molecular phylogenetic studies are inconclusive with respect to well supported clade delimitations and morphology. For example, the most comprehensive studies (Kårehed et al. 2008, Groeninckx et al. 2009) found that 
some species of the Borreria-Spermacoce complex appear intermingled among a few monophyletic and morphologically well-defined Spermacoceae genera [i.e., Mitracarpus Zuccarini (1827: 210), Richardia Linnaeus (1753: 330), and Psyllocarpus Martius \& Zuccarini (1824: 130)]. These studies aimed at resolving phylogenetic relationships within certain clades, as the "Oldenlandia-Hedyotis group" (Groeninckx et al. 2009, Wikström et al. 2013), or finding support for the description of new genera, as Amphistemon Groeninckx (2010: 450) and Thamnoldenlandia Groeninckx (2010: 458) (Groeninckx et al. 2010). However, sampling within the American Borreria-Spermacoce group has been very limited. Due to this limitation and such incongruences, the two genera are here maintained separate, following the generic delimitations adopted by our research group (Cabral et al. 2011, 2012a; Miguel \& Cabral 2013; Salas et al. 2011).

The species here treated have capsules with longitudinal dehiscence, stamens and style exserted, and a bifid stigma. These traits characterize Borreria subsection Latifoliae (Schumann 1888: 41) Bacigalupo \& E.L.Cabral (1996: 306), which includes ca. 10 species of herbs, erect or scandent subshrubs.

As part of a revision of the South American species of Borreria subsection Latifoliae, here we evaluate several unidentified specimens that might belong to two undescribed species displaying a peculiar and unusual phenomenon scarcely documented in Spermacoceae, and even in Rubiaceae. These two species have homostylous flowers with staminal dimorphism. In one of them, the dimorphism is due to different filaments lengths, while in the other species the stamens are inserted at two different levels in the corolla tube. As a result of the analyses of these species, we concluded that one of them is Borreria xanthophylla Bremekamp (1934: 306), a species not previously included in this group. Moreover, we discovered this staminal variation in two additional species of this subsection: $B$. hispida Spruce ex Schumann (1888: 62) and B. semiamplexicaule E.L. Cabral (1996: 37). Interestingly, the insertion of the stamens at different levels of the corolla tube was described and illustrated for the first time in the Latifoliae group by Aublet (1775) in Spermacoce alata Aublet (1775: 60, pl. 22, fig. 2, = Borreria alata (Aublet) Candolle (1830: 544)). However, this trait was overlooked and barely used by subsequent authors (Lamarck \& Poiret 1783; Wildenow 1798; Cuvier 1827; Don 1834).

Based on these observations and additional features, we describe Borreria heteranthera E.L. Cabral \& Sobrado as a new species from the state of Pará, Brazil, transfer B. xanthophylla to Borreria subsection Latifoliae, and complement the descriptions of B. hispida, B. semiamplexicaule and B. xanthophylla. We compare the staminal arrangements, pollen grains and seed morphology of these species. In addition, we indicate Borreria semiamplexicaule as a new record for Mato Grosso, Brazil and designate the lectotype for $B$. hispida. Finally, we compare the four species in a table with ecological, palynological, and morphological features (Table 1).

TABLE 1. Comparison of ecological, palynological and morphological features of Borreria heteranthera, B. hispida, B. semiamplexicaule and B. xanthophylla.

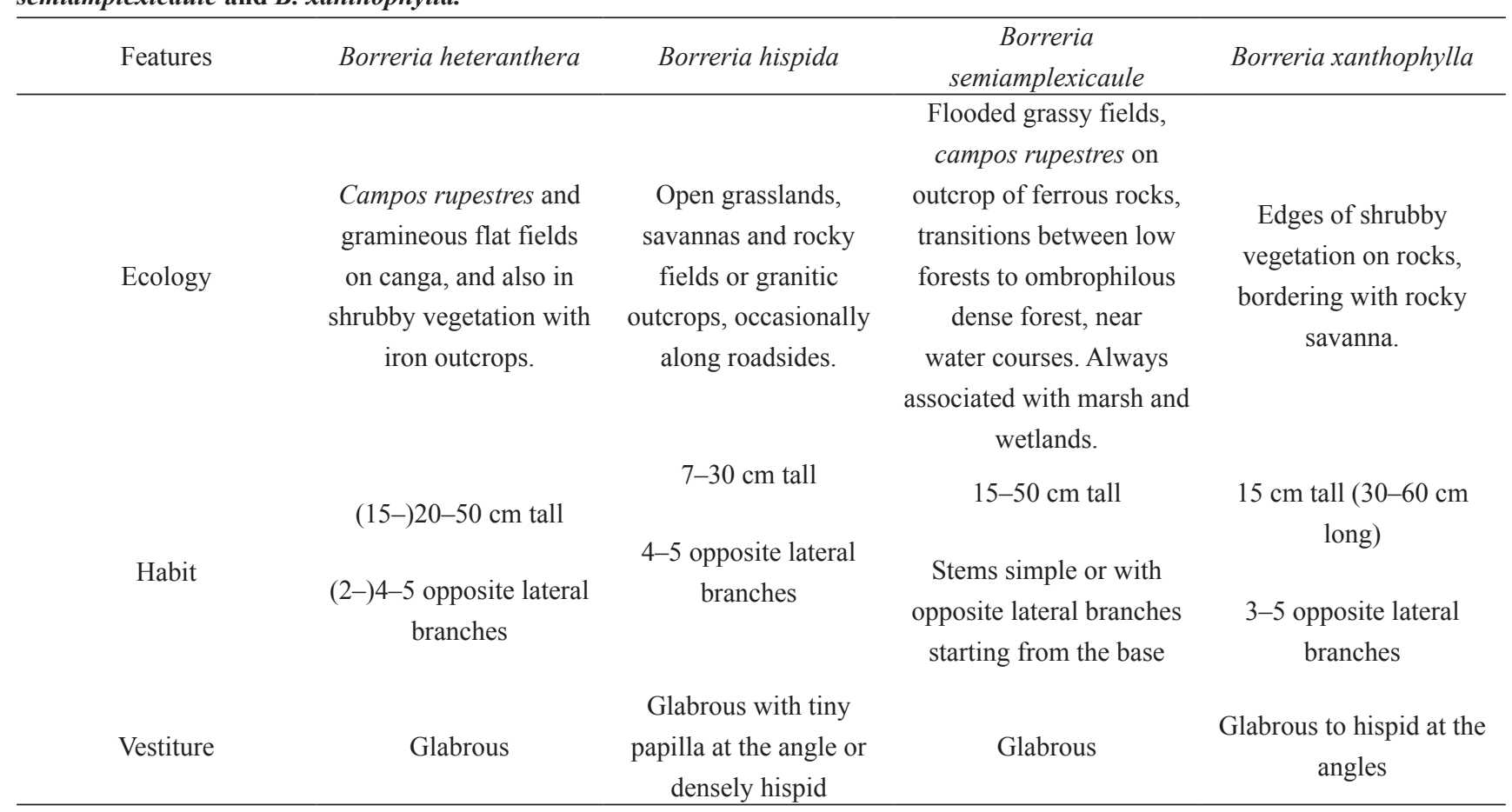

......continue on the next page 
TABLE 1. (Continued)

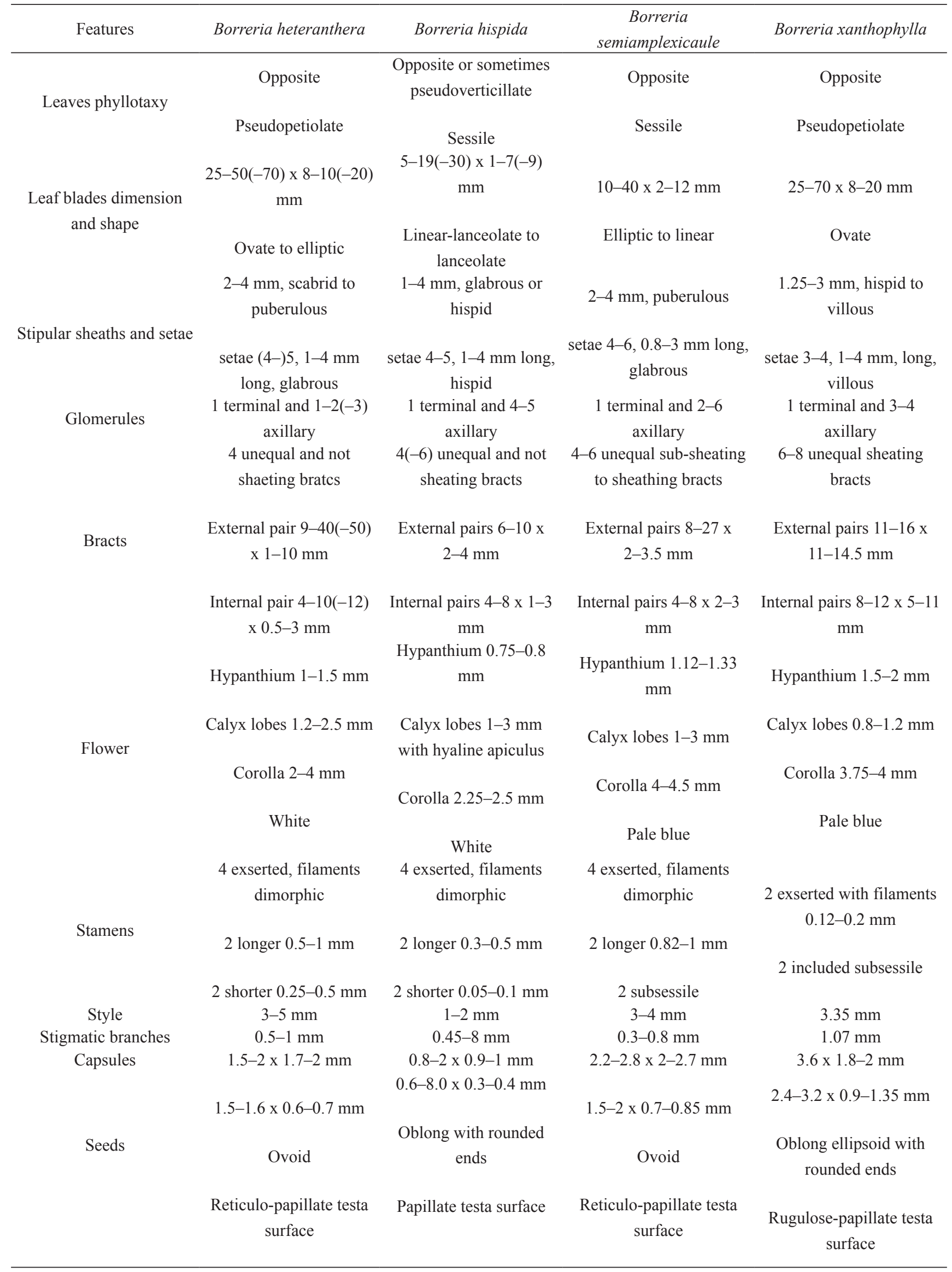


TABLE 1. (Continued)

\begin{tabular}{|c|c|c|c|c|}
\hline Features & Borreria heteranthera & Borreria hispida & $\begin{array}{c}\text { Borreria } \\
\text { semiamplexicaule }\end{array}$ & Borreria xanthophylla \\
\hline \multirow{3}{*}{ Pollen } & 9-10-zonocolpate & $8-9(-10)$-zonocolpate & 9-10(-11)-zonocolpate & 9-10-zonocolpate \\
\hline & \multicolumn{4}{|c|}{ Medium-sized } \\
\hline & $\begin{array}{l}\text { Oblate-spheroidal to } \\
\text { prolate-spheroidal }\end{array}$ & $\begin{array}{l}\text { Oblate-spheroidal to } \\
\text { prolate-spheroidal } \\
7(7.95) 10 \mu \mathrm{m}\end{array}$ & Oblate-spheroidal & Oblate-spheroidal \\
\hline Endocingulum at the & $10 \mu \mathrm{m}$ & $2 / 3$ the lenoth of & $7(8.43) 10 \mu \mathrm{m}$ & $4(4.2) 5 \mu \mathrm{m}$ \\
\hline $\begin{array}{c}\text { colpus area and relation } \\
\text { with } \mathrm{P} \text { axis }\end{array}$ & $\begin{array}{l}2 / 3 \text { the length of the } \\
\text { ectocolpus }\end{array}$ & $\begin{array}{l}\text { the ectocolpus, with } \\
\text { extension at the } \\
\text { mesocolpium }\end{array}$ & $\begin{array}{l}2 / 3 \text { the length of the } \\
\text { ectocolpus }\end{array}$ & $\begin{array}{l}1 / 3 \text { the length of the } \\
\text { ectocolpus }\end{array}$ \\
\hline & & Perforate ur & rmly spinulate & \\
\hline & \multicolumn{4}{|c|}{ Collumelar } \\
\hline Inner nexine surface & ------- & $\begin{array}{l}\text { Finely granular with } \\
\text { deep endocracks }\end{array}$ & $\begin{array}{c}\text { Finely granular with } \\
\text { superficial irregular } \\
\text { endocracks endocracks }\end{array}$ & ------ \\
\hline
\end{tabular}

\section{Material and Methods}

This study is based on recent collections, herbarium material from BHCB, BM, BR, CEN, CTES, HEPH, HUEFS, IAN, INPA, M, MBM, MG, MO, NY, P, R, RB, UB, and W (Thiers 2013), and images available on Jstor Plants (http:// plants.jstor.org). We used conventional taxonomic methods for the external morphology analyses and descriptions. Distribution is based on herbaria materials. The conservation status was proposed following the recommendations of IUCN Red List Categories and Criteria, Version 3.1 (IUCN 2012). GeoCAT (Bachman et al. 2011) was used for calculating the Extent of Occurrence (EOO) and the Area of Occurrence (AOO). The width of the grid followed the recommendations of IUCN (2012), being set at $2 \mathrm{~km}^{2}$.

We described the pollen grain and seed morphology based on the following samples taken from herbarium material: Borreria heteranthera: A. J. Arruda, P. L. Viana, F. M. Santos, P. B. Mayer, T. J. Battituci \& L. J. Arruda 826 (BHCB, CTES)*; Borreria hispida: R. Spruce (BM, R, NY, M, W), W. J. Burchell 8675 (BR)*, M. A. da Silva, R. C. Mendonça, N. G. Souza, N. R. Oliveira \& E. Cardoso 4033 (NY), A. Gröger 986 (M); Borreria semiamplexicaule: D. Daly, R. Callejas, M. G. da Silva, E. Taylor, C. Rosario \& M. dos Santos 1993 (CTES), P. M. Burkowski, A. J. Arruda, P. L. Viana, F. M. Santos \& T. J. Battituci 1187 (BHCB), P. L. Viana, F. S. Marino, A. J. Arruda, T. B. Jorge \& P. M. Burkowski 5269 (BHCB, CTES), A. J. Arruda, F. M. Santos, L. J. Arruda \& T. J. Battituci 928 (BHCB)*, A. J. Arruda, F. M. Santos, L. J. Arruda \& T. J. Battituci 1003 (BHCB)*, A. J. Arruda, F. M. Santos, L. J. Arruda \& T. J. Battituci

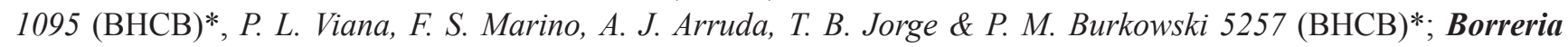
xanthophylla: J. J. de Granville, F. Crozier \& C. Sarthou 15017 (BR)*, R. Benoist 1507 (P). The specimens marked with an asterisk were also used for seed micromorphological analyses.

Pollen grains were acetolyzed according to Erdtman (1966) and mounted in glycerine jelly for analyses with a light microscope (LM). We measured the equatorial diameter (E), the polar axis (P), and the colpi and pori lengths in at least 20 grains under LM. To express the relative length of colpi we used the length colpi/polar axis rate multiplied by 100 (LC/P) (Dessein et al. 2002). All other measurements were made using scanning electron microscope (SEM) graphs. For SEM analyses, seeds and acetolyzed pollen grains were sputter-coated with gold, and then photographed with a Jeol 5800 LV SEM. Broken pollen grains were also observed with the SEM, to observe their internal morphology. Pollen terminology follows Punt et al. (2007) and seeds terminology follows Stearn (1986). 


\section{Results}

Two zygomorphic staminal arrangements were observed in the species of Borreria here treated. These features are the first record observed in homostylous species of Spermacoceae, and until now only found in these four species of the Borreria subsection Latifoliae. The configurations of insertion/length of the stamens are constant in all the examples and flowers of each species analyzed. Also, the pollen grain morphology is uniform in all anthers of the flower buds analyzed, independently of the staminal arrangement. This probably indicates that the different length or insertion of the stamens do not affect the pollen production and viability.

Staminal arrangements:- In Borreria heteranthera and B. semiamplexicaule the four exserted stamens are inserted at the sinuses of the corolla lobes, and both taxa, while being homostylous present dimorphic filaments. $B$. heteranthera has two stamens with shorter filaments, and other two with longer filaments (Figs. $3 \mathrm{H}, 4 \mathrm{C}$ ). While in B. semiamplexicaule the two shorter stamens have subsessile anthers (Figs. 6 I, 7 C-D). In contrast to this staminal arrangement, the other two species analyzed have stamens inserted at different levels in the corolla tube. In Borreria hispida two stamens are exserted and have longer filaments, while the other two are barely exserted and have shorter filaments (Fig. 5 F). In contrast, B. xanthophylla has two barely exserted stamens, and the other two are included and have subsessile anthers (Fig. $8 \mathrm{~J}$ ). In the last two species, the stamens with shorter filaments are inserted in the corolla tube, while the stamens with longer filaments are inserted at the interlobular sinuses.

Pollen grain morphology:- In Borreria heteranthera, pollen grains are 9-10-zonocolpate, medium-sized ( $\mathrm{P}=40$ (42.3) $44 \mu \mathrm{m}$; $\mathrm{E}=40$ (42) $45 \mu \mathrm{m}$ diam.), and oblate-spheroidal to prolate-spheroidal ( $\mathrm{P} / \mathrm{E}=0.98$ (1) 1.04). The outline is circular in polar view. The ectoaperture is a medium-sized, slit-like colpus ( $\mathrm{LC} / \mathrm{P}=30$ (32) 36). The endoaperture appears as a pore at SEM, whereas at LM analyses reveal that is an endocingulum; whose width is $2 / 3$ the length of the ectocolpus, with $10 \mu \mathrm{m}$ at the ectocolpus area. The tectum is perforate, uniformly spinulate, and $2-3 \mu \mathrm{m}$ thick; the infratectum is columellar. The perforations are subcircular or irregular, small and intermingled with larger ones, $0.16-0.26 \mu \mathrm{m}$. The nanospines $0.25-0.3 \mu \mathrm{m}$ long (Fig. $1 \mathrm{~A}-\mathrm{C}$ ).

In Borreria hispida, pollen grains are 8-9(-10)-zonocolpate, medium-sized ( $\mathrm{P}=29(33.94) 38 \mu \mathrm{m} ; \mathrm{E}=33(35.91)$ $43 \mu \mathrm{m}$ diam.), and oblate-spheroidal to prolate-spheroidal ( $\mathrm{P} / \mathrm{E}=0.86(0.94) 1.06)$. The outline is circular in polar view. The ectoaperture is a medium-sized, slit-like colpus ( $\mathrm{LC} / \mathrm{P}=26$ (32.78) 39). The endoaperture is similar to a pore when observed at LM, but in fact is an endocingulum; the width of the endoaperture is $2 / 3$ of the length of the ectocolpus, with extensions at the mesocolpium, 7 (7.95) $10 \mu \mathrm{m}$ long the ectocolpus area. The tectum is perforate, uniformly spinulate, and 2-2.5 $\mu \mathrm{m}$ thick; the infratectum is columellar. The perforations are subcircular and irregular, commalike, $0.2-0.4 \mu \mathrm{m}$. The nanospines are $0.3-0.4 \mu \mathrm{m}$ long. The inner nexine surface is finely granular with numerous broad and deep endocracks. (Figs. 1 D-F, 2 A-B).

In Borreria semiamplexicaule, pollen grains are 9-10(-11)-zonocolpate, medium-sized ( $\mathrm{P}=31$ (34.08) $39 \mu \mathrm{m}$; $\mathrm{E}=35$ (37.73) $40 \mu \mathrm{m}$ diam.) and oblate-spheroidal (P/E: $0.86(0.90) 0.98)$. The outline is circular in polar view. The ectoaperture is a medium-sized, slit-like colpus ( $\mathrm{LC} / \mathrm{P}=28$ (31.96) 38). The endoaperture is fused, forming an endocingulum; whose width is $2 / 3$ the length of the ectocolpus, with 7 (8.43) $10 \mu \mathrm{m}$ at the ectocolpus area. This was confirmed with LM analyses. The tectum is perforate, uniformly spinulate, and $2-3 \mu \mathrm{m}$ thick; the infratectum is columellar. The perforations are subcircular to irregular, comma-like, $0.2-0.4 \mu \mathrm{m}$. The nanospines are $0.4-0.5 \mu \mathrm{m}$ long. The inner nexine surface is very finely granular with superficial irregular endocracks (Figs. $1 \mathrm{G}-\mathrm{I}, 2 \mathrm{C}$ ).

In Borreria xanthophylla, pollen grains are 9-10-zonocolpate, medium-sized ( $\mathrm{P}=36(40.8) 45 \mu \mathrm{m} ; \mathrm{E}=40(42.5)$ $45 \mu \mathrm{m}$ diam.), and oblate-spheroidal $(\mathrm{P} / \mathrm{E}=0.84(0.91) 1)$. The outline is circular in polar view. The ectoaperture is a short, slit-like colpus ( $\mathrm{LC} / \mathrm{P}=23$ (24.64) 27). The endoaperture is an endocingulum confirmed at LM; whose width is $1 / 3$ the length of the ectocolpus, with 4 (4.2) $5 \mu \mathrm{m}$ at the ectocolpus area. The tectum is perforate, uniformly spinulate, and $1.3-1.6 \mu \mathrm{m}$ thick; the infratectum is columellar. The perforations are subcircular, $0.22-0.42 \mu \mathrm{m}$. The nanospines are $0.3-0.6 \mu \mathrm{m}$ long. The inner nexine surface is finely granular. (Figs. $1 \mathrm{~J}-\mathrm{L}, 2 \mathrm{D}$ ). 

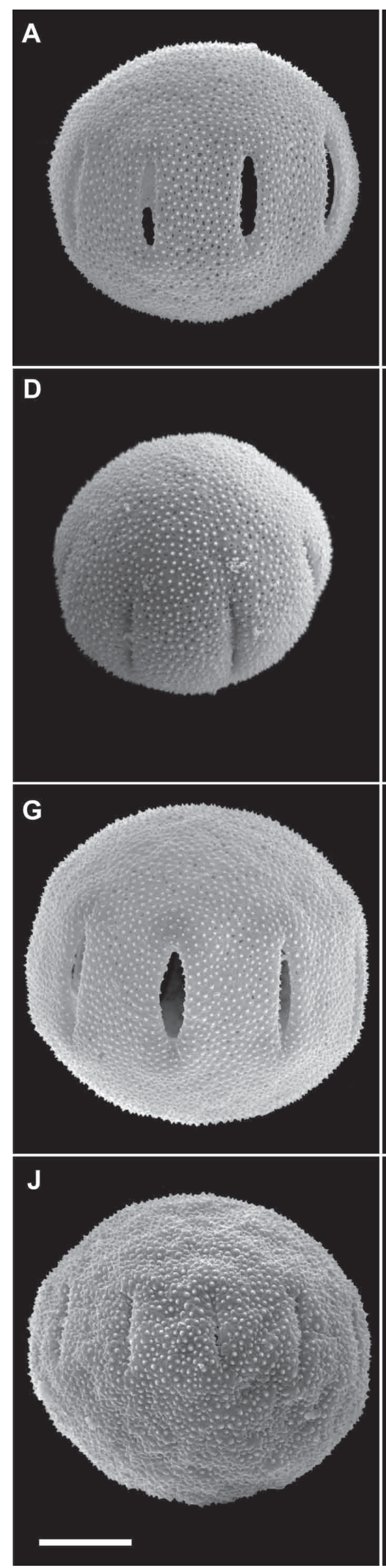

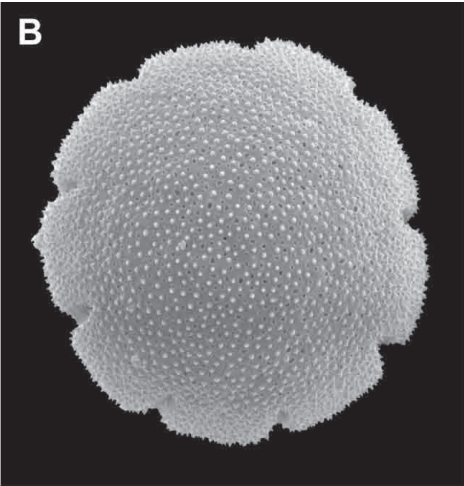

$\mathbf{E}$

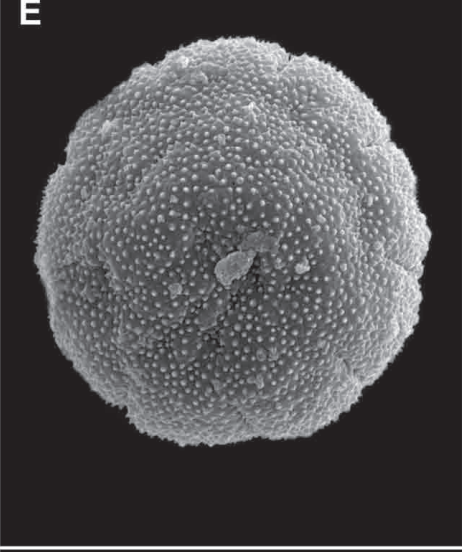

H

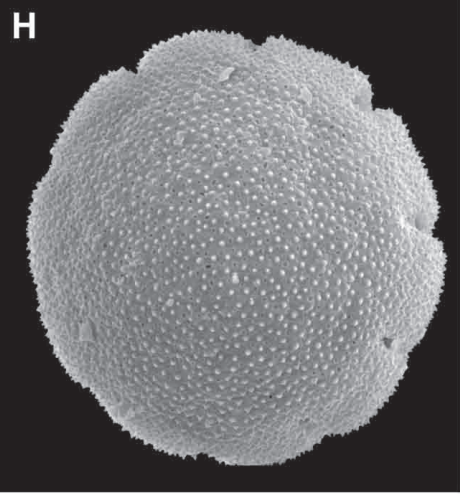

K

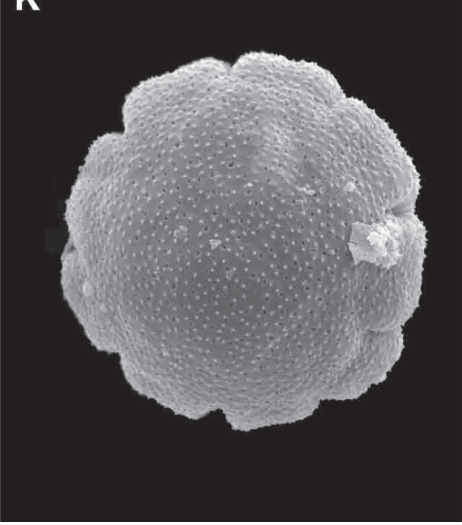

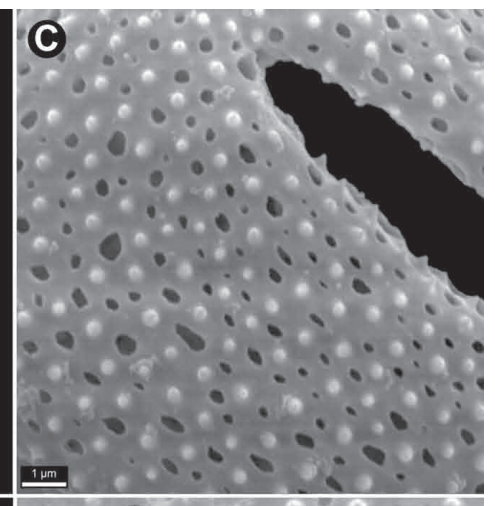

(F)
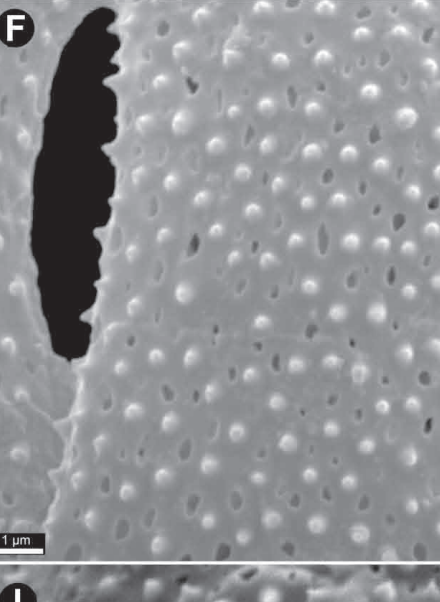

(1)

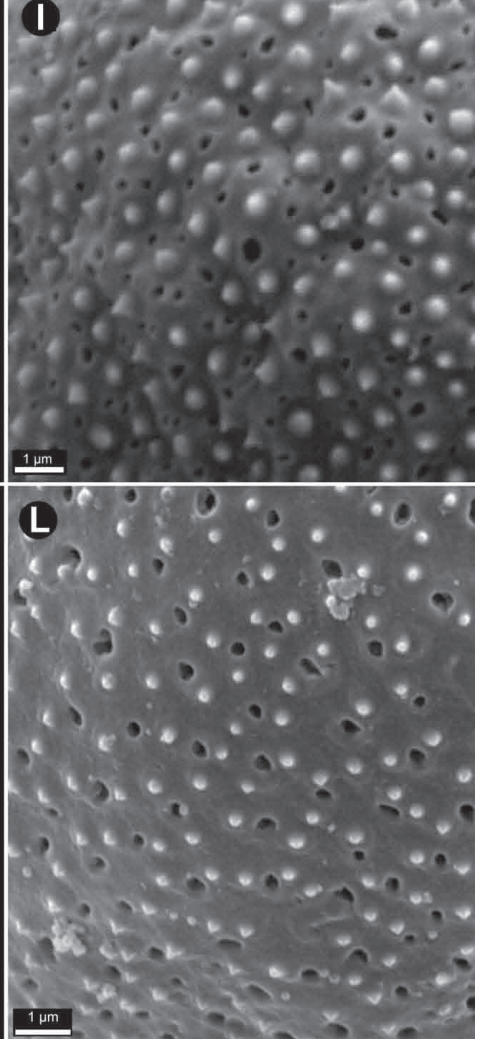

FIGURE 1. Scanning electron microscopy (SEM) micrographs of pollen grains. Borreria heteranthera (A-C from A. J. Arruda, P. L. Viana , F. M. Santos, P. B. Mayer, T. J. Battituci \& L. J. Arruda 826). A. Equatorial view. B. Polar view. C. Detail of mesocolpium and a section of the colpus. Borreria hispida (D-E from R. Spruce 663; F from A. Gröger 986). D. Equatorial view. E. Polar view. F. Detail of mesocolpium and a section of the colpus. Borreria semiamplexicaule (G-H from P. M. Burkowski, A. J. Arruda, P. L. Viana, F. M. Santos \& T. J. Battituci 1187; I from D. Daly, R. Callejas, M. G. da Silva, E. Taylor, C. Rosario \& M. dos Santos 1993). G. Equatorial view. H. Polar view. I. Detail of apocolpium. Borreria xanthophylla (J-L from J. J. de Granville, F. Crozier \& C. Sarthou 15017). J. Equatorial view. K. Polar view. L. Detail of apocolpium. Scale bar $10 \mu \mathrm{m}$. 


\section{Taxonomy}

Borreria heteranthera E.L. Cabral \& Sobrado, sp nov. (Figs. 1 A-C, 3 A-L, 4 A-C, 9 A-C)

Type:-BRAZIL, Pará, Canaã dos Carajás, S11A, 6²0’47” S, 50²5’52” W, 737 m, 25 April 2012, A. J. Arruda, F. M. Santos, L. J. Arruda \& T. J. Battituci 1099 (holotype BHCB 158091!; isotype CTES!).

Borreria heteranthera is similar to $B$. semiamplexicaule in being an annual herb, with two pairs of unequal involucral bracts, and papillate seeds; the former differs from the latter in having non-sheathing bracts (vs. sheathing in $B$. semiamplexicaule), the external pair of bracts 9-40 (50) $\times 1-10 \mathrm{~mm}(\mathrm{vs} .8-27 \times 2-3.5 \mathrm{~mm})$, the internal pair of bracts 4-10 (12) $\times 0.5-3 \mathrm{~mm}$ (vs. 4.4-8 $\times 2-3.2 \mathrm{~mm}$ ), and two long and two short filaments (vs. two long filaments and two subsessile anthers).

Annual erect herb, (15-)20-50 cm tall; stems with (2-)4-5 opposite lateral branches or rarely simple, subquadrangular at the base, quadrangular and winged in young growth, glabrous, internodes $4-8 \mathrm{~cm}$ long. Stipular sheaths 2-4 mm long, scabrid to puberulous; setae (4-)5, 1-4 mm long, glabrous and colleter-tipped. Leaves opposite, pseudo-petiolate; blades ovate to elliptic, $25-50(-70) \times 8-10(-20) \mathrm{mm}$, attenuate at base, acute at apex, membranaceous, glabrous above, puberulous or scabrid underneath, margin scaberulous, main nerve weakly marked; secondary veins inconspicuous. Inflorescences with 1 terminal and 1-2(-3) axillary glomerules, on principal stems and opposite lateral branches, pauciflorous; bracts 4, unequal, not sheathing, the larger and external pair of bracts $9-40(-50) \times 1-10 \mathrm{~mm}$, the smaller and internal pair of bracts 4-10(-12) $\times 0.5-3 \mathrm{~mm}$. Flowers 4-merous, subsessile (pedicels $0.4-0.5 \mathrm{~mm}$ long). Hypanthium obpiriform, 1-1.5 mm long, scabrulous. Calyx lobes subtriangular, 1-2.5 mm long, with external side and margins scabrulous, with vinaceous hairs. Corolla infundibuliform, 2-4 mm long, white, yellow-green when dry; tube 2.3-2.8 mm long, externally glabrous, internally with a ring of moniliform hairs near the base; lobes triangular, $0.8-2$ $\mathrm{mm}$ long, shorter than the tube, with 2-3 teeth at the apex outside, with a few scattered moniliform hairs at base inside. Stamens exserted, filaments dimorphic, inserted at the sinuses of the corolla lobes, papillate, the 2 longer filaments $0.5-1 \mathrm{~mm}$ long, the 2 shorter filaments $0.25-0.5 \mathrm{~mm}$ long; anthers oblong, $0.4-0.6 \times 0.3-0.4 \mathrm{~mm}$. Style exserted, 3-5 $\mathrm{mm}$ long, bifid, style branches $0.5-1 \mathrm{~mm}$ long, papillate; nectary disc bipartite. Capsules subsessile (pedicels 0.6-1 $\mathrm{mm}$ long), ovoid, 1.5-2 × 1.7-2 mm, glabrous, with 2 septicidally dehiscent valves. Seeds ovoid, $1.5-1.6 \times 0.6-0.7$ $\mathrm{mm}$, dark brown; dorsal surface convex, ventral surface with a deep groove, covered by hyaline strophiole and some sparse raphids; testa reticulo-papillate, cells digitate, periclinal walls convex with a subcircular depression and a little excrescence at the apex, anticlinal walls curved or sinuous (Fig. 9 A-C).

Distribution:-Borreria heteranthera is endemic to Serra dos Carajás, an isolated mountain range on the eastern Amazon area, in Pará State, Brazil. It grows particularly at the Serra Norte and Sul from Parabuapebas and Canaã dos Carajás municipalities.

Ecology and Phenology:- Growing in campos ruprestres and gramineous flat fields on canga, and in shrubby vegetation with iron-rich rocks outcrops, on mountain summits, at 600-800 m elevation; flowering and fruiting from February to May. The vegetation of this area is characterized by evergreen, semideciduous, and deciduous forests, and by patches of saxicolous shrubby vegetation called canga (Secco \& Mesquita 1983) or campos rupestres (i.e., rochy outcrops; Silva et al. 1996).

Conservation status:-According to the IUCN criteria (IUCN 2012) Borreria heternathera should be classified as endangered [EN B2ab(ii, iii, iv)]. The extent of occurrence (EOO) is calculated to be $15.424 \mathrm{~km}^{2}$, and the area of occupancy (AOO) is estimated at $20.000 \mathrm{~km}^{2}$ (cell sized $2 \mathrm{~km}$ ) in a fragmented area. The species is known from several localities, representing two locations from the northern of Pará State. The region where Serra dos Carjás is located is experiencing mining activity, especially linked to the exploitation of ferrous material, threatening the local natural vegetation.

Additional specimens examined:-BRASIL. Pará: Canaã dos Carajás: Serra Sul, Corpo B, 621'19" S, 50²3’26” W, 700 m, 19 March 2009, P. L. Viana, L. M. Versieux, L. C. Garcia, V. T. Giorni, L. V. C. Silva \& D. S. Silva 4150 (BHCB); Corpo D, 6²3'54” S, 50²2’12” W, 700 m, 17 March 2009, P. L. Viana, L. M. Versieux, L. C. Garcia, V. T. Giorni, L. V. C. Silva \& D. S. Silva 4094 (BHCB); Serra do Tarzan, 6¹9'12” S, 506’3” W, 600-800 m, 19 February 2010, L. V. Costa, D. T. Souza, A. J. Arruda, F. Dayrell, F. Costa \& T. Aaimeida 819 (BHCB); S11-A, $6^{\circ} 19^{\prime} 5^{\prime}$ S, 50²6’44” W, 735 m, 27 March 2012, A. J. Arruda, P. L. Viana, F. M. Santos, P. B. Mayer, T. J. Battituci \& L. J. Arruda 909 (BHCB); S11-A, 6²0’47” S, 50²5’52” W, 737 m, 25 April 2012, A. J. Arruda, F. M. Santos, L. J. Arruda \& T. J. Battituci 1098 (BHCB, CTES). Parauapebas: Flona dos Carajás, Serra Sul-S11, Corpo D, 6²3'40" S, 50²1'51” W, 733 m, 20 March 2012, P. L. Viana, F. S. Marino, A. J. Arruda, T. B. Jorge \& P. M. Burkowski 5226 
(BHCB, CTES); N4-WS, 64'24” S, 50¹1'35”'W, 554 m, 24 March 2012, A. J. Arruda, P. L . Viana, F. M. Santos, P. B. Mayer, T. J. Battituci \& L. J. Arruda 822 (BHCB, CTES); N4-WS, 64'22” S, 50¹1'42”' W, 505 m, 24 March 2012 , A. J. Arruda, P. L. Viana, F. M. Santos, P. B. Mayer, T. J. Battituci \& L. J. Arruda 826 (BHCB, CTES).
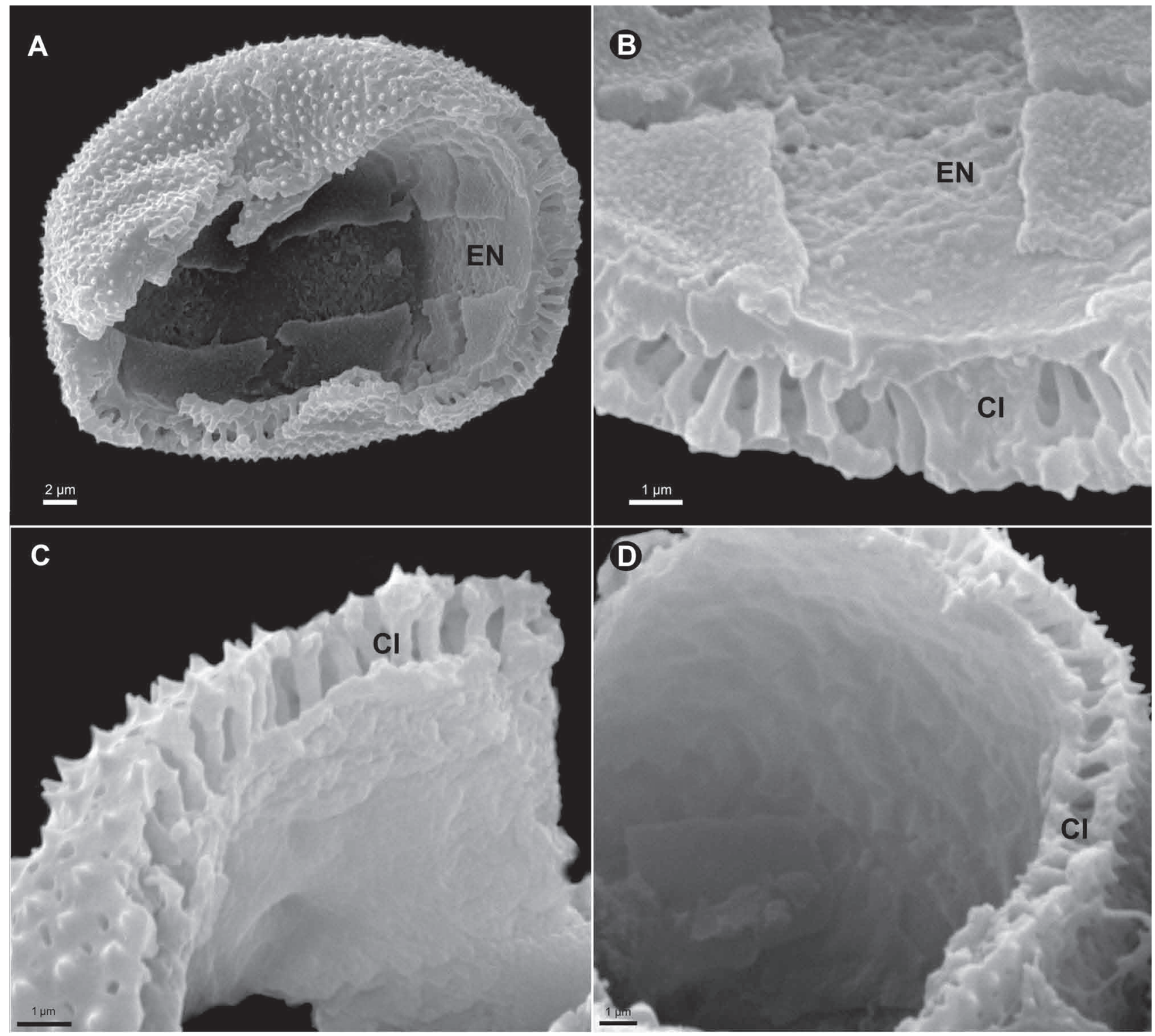

FIGURE 2. Scanning electron microscopy (SEM) micrographs of the pollen wall stratification, the inner nexine surface and the endoaperture morphology. A-B. Borreria hispida (from R. Spruce 663). A. Inside of pollen fragment with an endocingulum (EN) and nexine surface finely granular with broad and deep endocracks. B. Detail of a section of the endocingulum (EN) and the columellar infratectum (CI). C. Borreria semiamplexicaule (from D. Daly, R. Callejas, M. G. da Silva, E. Taylor, C. Rosario \& M. dos Santos 1993). View of inner nexine surface finely granular with superficial irregular endocracks. Note the columellar infratectum (CI). D. Borreria xanthophylla (from J. J. de Granville, F. Crozier \& C. Sarthou 15017). View of inner side of a portion of broken pollen showing the columellar infratectum (CI) and the finely granular inner nexine surface.

Borreria hispida Spruce ex K. Schum., in Mart., Fl. Bras. 6(6): 62. 1888. Spermacoce neohispida Govaerts, World Checkl. Seed P1. 2(1): 18. 1996. Type:-BRAZIL. Pará: Santarem, April 1850, R. Spruce 663 (lectotype M!, designated here; Isolectotypes BM!, FI (JSTOR-image)!, K (JSTOR-image)!, MPU (JSTOR-image)!, NY!, RB!, R!, S (JSTORimage)!, TCD (JSTOR-image)!, W!. (Figs. 1 D-F, 2 A-B, 5 A-J, 9 D-F).

Borreria hispida Spruce ex K. Schum. var. glabrescens K. Schum. in Mart., Fl. Bras. 6(6): 62. 1888. Type:-BRAZIL. "Goyaz prope Porto Real” [now Tocantins: Porto Nacional], s.d., W. J. Burchell 8675 (lectotype NY, designated by Delprete (2010: 1221); isolectotypes BR!, F!). 


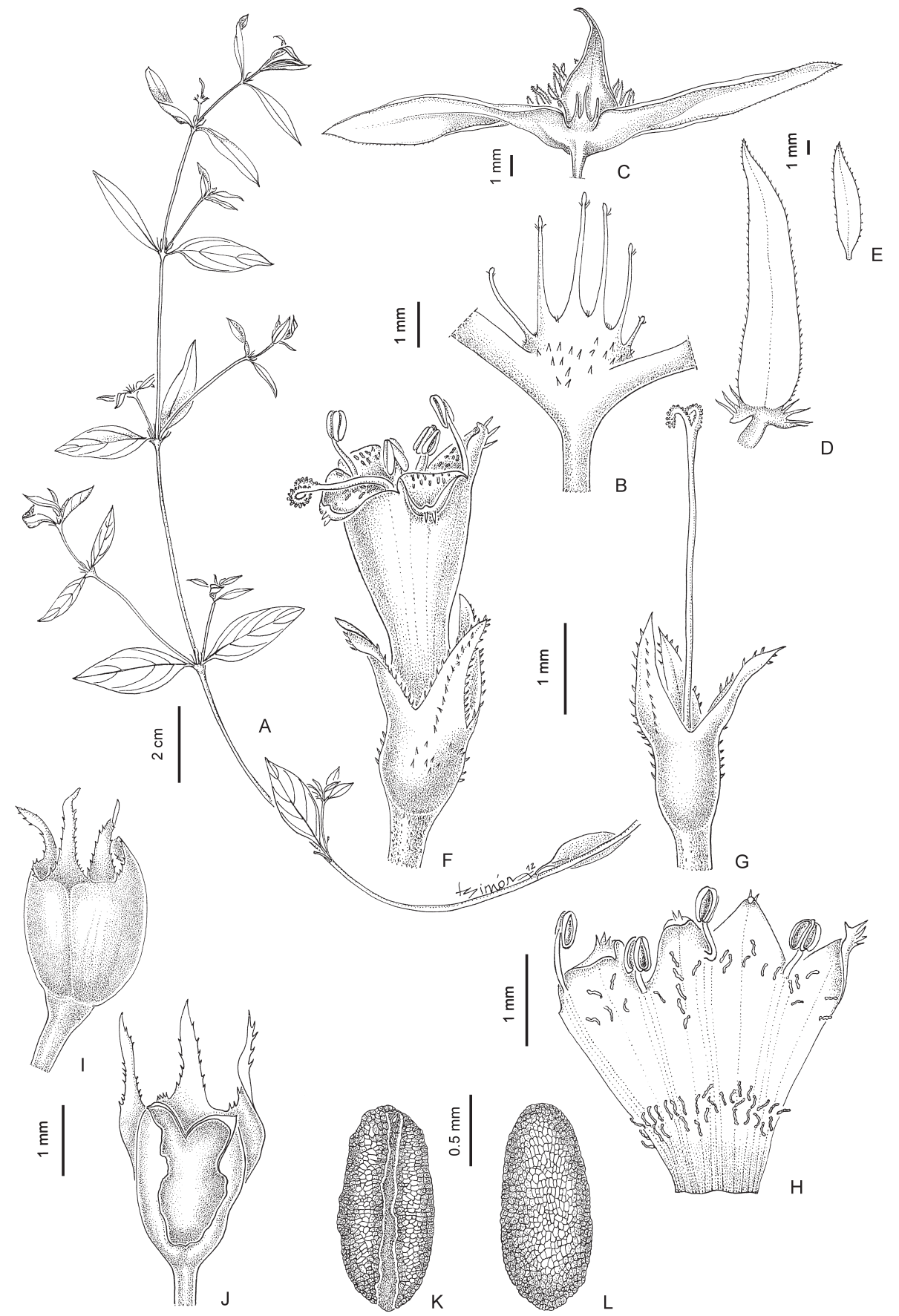

FIGURE 3. Borreria heteranthera E.L. Cabral \& Sobrado. A. Habit. B. Stipular sheath. C. Terminal glomerule. D. Detail of external bract. E. Detail of internal bract. F. Flower. G. Hypanthium, style and stigma. H. Open corolla. I. Capsule. J. Internal view of mericarp to display septicidal dehiscence. K. Ventral view of seed. L. Dorsal view of seed. (A, B, F-H from P. L. Viana, L. M. Versieux, L. C. Garcia, V. T. Giorni, L. V. C. Silva \& D. S. Silva 4094; C, I-L from A. J. Arruda, P. L. Viana, F. M. Santos, P. B. Mayer, T. J. Battituci \& L. J. Arruda 909; D, E from A. J. Arruda, F. M. Santos, L. J. Arruda \& T. J. Battituci 1099). Illustration by L. Simón.

Annual erect o rarely semi-prostrate herb, 7-30 cm tall; stems ramose at the base or simple with 4-5 opposite lateral branches, tetragon, slightly winged, glabrous with tiny papilla at the angle or densely hispid at the young braches, internodes 10-20(-40) $\mathrm{mm}$ long. Stipular sheaths subtriangular, 1-4 mm long, glabrous or hispid; setae 4-5, 1-4 $\mathrm{mm}$ long, hispid and colleter-tipped. Leaves opposite or sometimes pseudoverticillate (due to axillary brachiblasts), sessile or rarely pseudopetiolate; blades linear-lanceolate to lanceolate, $5-19(-30) \times 1-7(-9) \mathrm{mm}$, attenuate at base, acute at apex, papery, glabrous, puberulous to pubescent above, densely pilose below, principally on secondary veins, margins revolute, scabrous. Inflorescences with 1 terminal and 4-5 axillary glomerules, on principal stems and opposite lateral branches, pauciflorous; bracts 4(-6), unequal, not sheathing, ovate-lanceolate, base subcordate, 
the larger and external pair of bracts $6-10 \times 2-4 \mathrm{~mm}, 2-4$, the smaller internal bracts $4-8 \times 1-3 \mathrm{~mm}$ long, absent in axillary glomerules. Flowers 4-merous, subsessile (pedicels $0.1-0.2 \mathrm{~mm}$ long). Hypanthium obconic, 0.75-0.8 mm long, glabrous, puberulous or with sparse hispid hairs. Calyx lobes lanceolate to triangular, 1-3 mm long, glabrous, scabrulous or hispid, with hyaline apiculus, $0.5-0.65 \mathrm{~mm}$ long. Corolla infundibuliform, $2.25-2.5 \mathrm{~mm}$ long, white; tube 1-2 mm long, glabrous outside, with a ring of moniliform hairs at $1 / 3$ from the base inside; lobes triangular, $0.5-1 \mathrm{~mm}$ long, with $2-3$ teeth at the apex outside. Stamens exserted, with dimorphic filaments, the 2 longer filaments inserted at the sinuses of the corolla lobes, $0.3-0.5 \mathrm{~mm}$ long, the 2 shorter filaments inserted at the top of the corolla tube, $0.05-0.1 \mathrm{~mm}$ long, anthers oblong $0.35-0.3 \times 0.25-0.2 \mathrm{~mm}$. Style exserted, $1-2 \mathrm{~mm}$ long, bifid; style branches $0.45-0.8 \mathrm{~mm}$ long, stigmatic surface papillate; nectary disc bipartite. Capsules subsessile (pedicels $0.2-0.8 \mathrm{~mm}$ long), subglobose, $0.8-2 \times 0.9-1 \mathrm{~mm}$, hispid at the sepals, with 2 septicidally dehiscent valves. Seeds oblong, $0.6-0.8 \times$ 0.3-0.4 mm, round at both ends, base acuminate, dark brown; dorsal surface convex, ventral surface flat with a broad groove covered by strophiole exceeding the apex of the seed with some raphids; testa surface papillate, cells digitate, periclinal wall convex with rounded ends, anticlinal walls sinuous (Fig. 9 D-F).

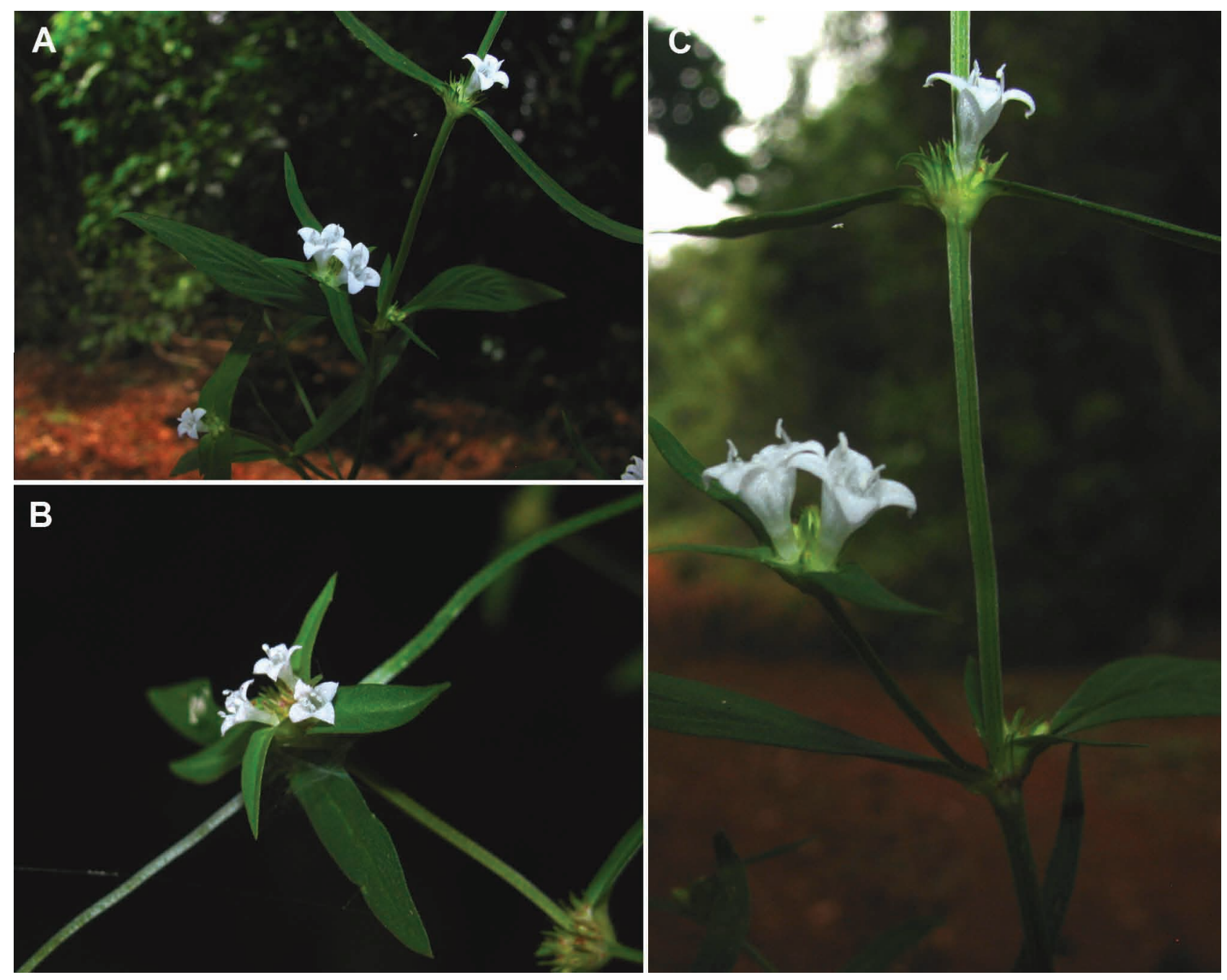

FIGURE 4. Borreria heteranthera E.L. Cabral \& Sobrado. A. Habit. B. Detail of terminal glomerule. C. Flowers. Photographs by A. J. Arruda.

Distribution:- Central and northern Brazil, French Guiana, Guyana, Suriname and Venezuela; at 800-1000 m elevation.

Ecology and Phenology:- Open grasslands, savannas and rocky fields or granitic outcrops, occasionally along roadsides. Flowering and fruiting from November to July.

Remarks:-Schumann (1888) described Borreria hispida and cited two collections in Flora Brasiliensis: Leprieur s.n. from French Guiana, and Spruce 663 from Pará, Brazil. The specimen collected by Leprieur could not be located in this study. Spruce 663 at the Martius herbarium in Munich (M) is well-preserved and has at least 10 duplicates distributed in numerous herbaria. For this reason, we select Spruce 663 at $\mathrm{M}$ as the lectotype of this taxon. Besides this, 
we consider important to remark a controversial situation about the Spruce collection number cited in the protologue of the species. The label of the M specimen has the number " 663 " handwritten with a different calligraphy (author unknown) from the original dates. Also, the label has the signature and the annotation "K. Schum.!". This proves that Schumann saw this specimen, and cited this number in the species protologue. However, not all the available specimens of Spruce collected in "Prope Santarem, Pará, Brazil, April of 1950" has the same number written in its labels (i.e. JSTOR images from FI, K, MPU, S, and TCD herbaria). Also, the BM and NY specimens have labels annotated with this different calligraphy. Taking into account this handwritten annotation from all specimens analyzed, we think that this number does not correspond to Spruce's collection number. However, we preferred to maintain 663 as Spruce's collection number because its extensive use in the literature.

Conservation status:-According to the area of occupancy estimated (AOO: 152,000 $\mathrm{km}^{2}$; cell size $2 \mathrm{~km}$ ) and following the IUCN criteria (2012), Borreria hispida should be considered as least concern. This is a widespread and well-collected species in several locations from open grasslands and granitic outcrops of the Guianas, Brazil, and Venezuela. The extent of occurrence (EOO) is calculated to be $4,836,460.459 \mathrm{~km}^{2}$.

Additional specimens examined:-BRASIL. Amapá: Rio Araguari, 20 September 1961, J. M. Pires, W. Rodrigues \& G. C. Irvine 51129 (NY); Road to Amapá, 017’ N, 515' W, 7 July 1962, J. M. Pires \& P. B. Cavalcante 51970 (IAN, NY); Estrada de Curiaú, Macapá, 22 June 1982, B. V. Rabelo \& R. Non 1607 (F, UB); 8 April 1982, N. A. Rosa, M. R. Santos \& S. S. Silva 4183 (INPA, MG, NY). Amazonas: Rio Negro, June 1910, E. H. G. Ule 8974 (F, MG). Goiás: 10 km S of Guará, 550 m, 18 March 1968, H. S. Irwin, H. Maxwell \& D. C. Wasshausen 21332 (NY); idem, H. S. Irwin, H. Maxwell \& D. C. Wasshausen 21338 (MO, NY); Pirenópolis, Serra dos Pireneus, 1549'22" S, 48 53'20" W, 1040 m, 18 March 2006, P. G. Delprete, V. L. Gomes-Klein \& O. Yano 9538 (NY, RB); idem, 1547'59” S, 4853'51” W, 1070 m, 19 March 2006, P. G. Delprete, V. L. Gomes-Klein \& O. Yano 9616 (NY). Maranhão: Balsas, 7³5' S, 46 5' W, 300 m, 21 March 1997, R. C. Oliveira \& G. P. da Silva 601 (CTES, HEPH); idem, Condominio Kissy Lote 23, 20 March 1999, G. Pereira-Silva 4122 (CEN, CTES, JPB). Pará: Jari, Agua Branca, km 3, 28 July 1969, N. T. da Silva 2499 (NY, UB); Santarum, 21 June 1910, A. Ducke 23140 (MG, RB); Guarai, Rod. Belem-Brasilia, 30

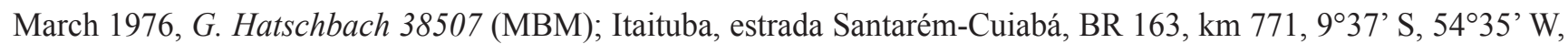
22 April 1983, I. L. Amaral, N. Silva, O. P. Monteiro, J. Lima, L. Brako, W. D. Reese \& M. Dibben 878 (INPA, MG, NY, RB); Santarém, Alter do Chão, 21 May 1910, A. Ducke 10796 (F, MG, RB); idem, 8 June 1987, W. E. Magnusson \& I. S. Miranda s.n. (INPA 163.615); idem, 23 June 1988, I. S. Miranda s.n. (INPA 163.614); Serra do Cachimbo, 320 m, 20 February 1977, J. H. Jr. Kirkbride \& E. Lleras 2953 (MO); Guajara Mirim, 1044' S, 65²15' W, 10 April 1987, M. Nee 34766 (INPA, MO); Ji-Paraná, Reserva Biológica do Jaru, 2³7’12.07” S, 61³6’53.39” W, 4 May 2006, J. F. Ramos \& A. M. G. Anjos 2909 (INPA). Tocantins: ca. $15 \mathrm{~km} \mathrm{~S}$ of Araguaína, 300 m, 15 March 1968, H. S. Irwin, H. Maxwell \& D. C. Wasshausen 21195 (F, MG, NY, RB); Lagoa da Confusão, Ilha do Bananal, 10²7'5” S, 50॰29'58” W, 270 m, 20 March 1999, M. A. Silva, A. D. dos Santos, A. Pires da Silva, N. R. Oliveira, N. G. Souza, R. C. Mendonça \& E. Cardoso 4010 (NY); idem, 265 m, 21 March 1999, M. A. da Silva, R. C. Mendonça, N. G. Souza, N. R. Oliveira \& E. Cardoso 4033 (NY). GUYANA. East Berbice-Corentyne Region, S Awara Savanna, 543' N, 57 $32^{\prime}$ W, 1-25 m, 18 December 1986, J. J. Pipoly, G. Gharbarran \& G. Bacchus 9380 (MO); 5³3' N, 57²40' W, 10-20 m, 29 October 1989, L. J. Gillespie, C. Kelloff \& S. Tiwari 2532 (MO, NY); Rupununi, Dadanawa, 249’ N, 59³1’ W, 120 m, 6 June 1995, M. J. Jansen-Jacobs, B. J. H. ter Welle, C. Gustafsson \& V. James 3929 (F). FRENCH GUIANA. Kourou, 8 April 1985, C. Feuillet 1657 (MO, P). SURINAME. Saramacca, Tibiti savanne, 13 January 1949, J. Lanjouw \& J. C. Lindeman 1799 (NY, U); idem, 20 May 1976, L. B. B. Tenuissen 16144 (U); Sipaliwini Savanna, 24 August 1966, J. van Donselaar 3562 (U). VENEZUELA. Anzoátegui: Bolívar, 10²' N, 64²17' W, 1100 m, 24 November 1981, G. Davidse \& A. C. González 19334 (NY, MO). Amazonas: Savanna of Atures, 31 July 1887, A. Gaillard 229 (F, P); vicinity of Sanariapo, near Río Sanariapo, 100 m, 8 September 1944, J. A. Steyermark 58458 (F); Atures, 548' N, 67²0’ W, 80 m, 23 September 1980, O. Huber 5713 (NY); idem, 19 August 1980, O. Huber 5608 (NY); Puerto Ayacucho, 5³9' N, 67³8' W, 100 m, 22 November 1984, T. B. Croat 59218 (MO); idem, 23 November 1984, R. L. Liesner 17230 (NY, MO); Atures, 534’ N, 67³5’ W, 21 July 1993, A. Gröger 986 (M). Apure: Puerto Paez, 200 m,

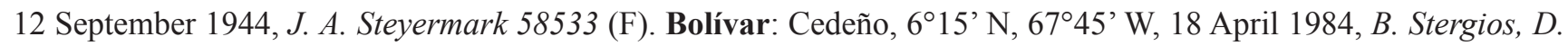
Taphora \& L. Nico 7223 (MO); idem, 7³6' N, 66¹5' W, 100-200 m, 2 September 1985, J. A. Steyermark, B. Holst \& B. Manara 131230 (MO); idem, 4³0’ N, 6130’ W, 850 m, 1 November 1985, R. L. Liesner 19285 (MO); Gran Sabana, between Kun and waterfall at Ruémerú, south of Mount Roraima, 1065 m, 2 October 1944, J. A. Steyermark 59168 (F, NY). Portuguesa: 9¹8’30” N, 6942’ W, 500 m, 3 November 1982, Anonymous 127263 (MO 3111618); idem, 98' N, 6942' W, 900 m, 8 September 1985, B. Stergios, G. Aymard, O. Hubber \& W. Morawertz 8709 (MO). Yaracuy: 4 km N of Salom, 1000 m, 20 October 1982, G. Davidse, R. Liesner \& J. A. Steyermark 20778 (MO). 


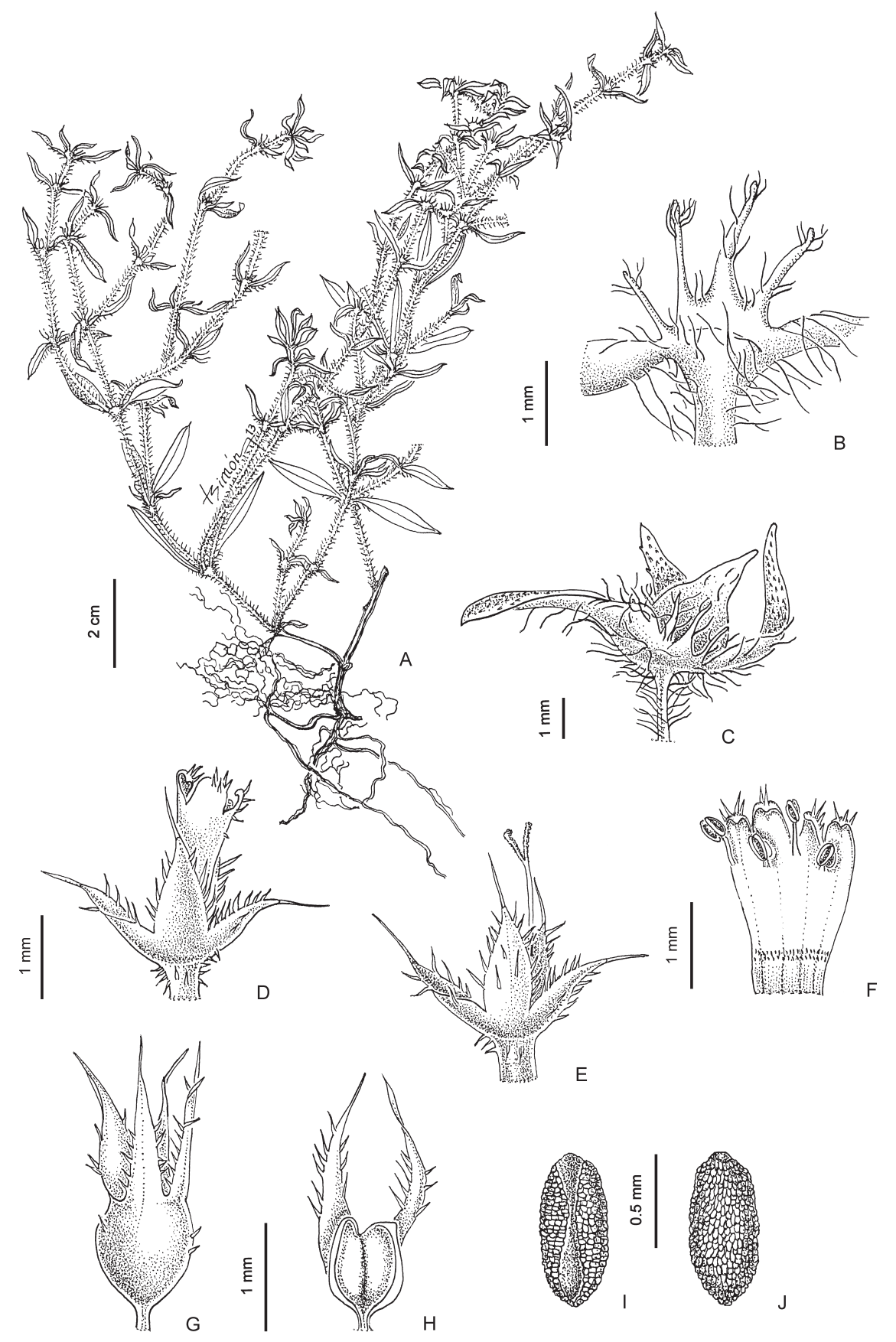

FIGURE 5. Borreria hispida Spruce ex K. Schum. A. Habit. B. Stipular sheath. C. Terminal glomerule. D. Flower. E. Hypanthium, style and stigma. F. Open corolla. G. Capsule. H. Internal view of mericarp to display septicidal dehiscence. I. Ventral view of seed. J. Dorsal view of seed. (A-J from R. Spruce 663). Illustration by L. Simón.

Borreria semiamplexicaule E.L. Cabral, Bonpandia 9: 37. 1996. Spermacoce semiamplexicaule(E.L. Cabral) Delprete, J. Bot. Res. Inst. Texas 1(2): 1028. 2007. Type:-BRAZIL, Pará, $25 \mathrm{~km} \mathrm{NW}$ of camp at Serra Norte, approx. 554' S, 50²7’ W, 13 December 1981, D. Daly, R. Callejas, M. G. da Silva, E. Taylor, C. Rosario \& M. dos Santos 1993 (holotype: NY!; isotype: CTES!). (Figs. 1 G-H, 2 C, 6 A-M, 7 A-F, 9 G-I).

Annual herb, erect, 15-50 cm tall; stems simple or with opposite lateral branches starting from the base, subtetragonal, slightly winged, glabrous, internodes $3-8 \mathrm{~cm}$ long. Stipular sheaths $2-4 \mathrm{~mm}$ long, puberulous at the upper third; setae 4-6, 0.8-3 mm long; stipular sheath from the terminal glomerule with 3-4 setae. Leaves opposites, sessile; blades elliptic to linear, 10-40 $\times 2-12 \mathrm{~mm}$, attenuate at base, acute at apex, membranaceous, margin with rough papillae, midrib conspicuous on the lower surface, secondary veins less evident. Inflorescences with 1 terminal and 
2-6 axillary glomerules, pauciflorous; bracts 4-6, unequal, sub-sheathing to sheathing, base cordate to auriculate, the 2 larger external bracts $8-27 \times 2-3.5 \mathrm{~mm}$, the $2-4$ smaller internal bracts $4-8 \times 2-3 \mathrm{~mm}$. Flowers 4-merous, subsessile (pedicels $0.35 \mathrm{~mm}$ long). Hypanthium obconic, $1.12-1.33 \mathrm{~mm}$ long, glabrous. Calyx lobes triangular, 1-3 mm long, margins with rough papillae or with red scabrous hairs. Corolla infundibuliform, 4-4.5 $\mathrm{mm}$ long, pale blue, rare white; tube 3.5-4.4 mm long, glabrous outside, with a ring of moniliform hairs near the base inside; lobes triangular, 1.2-1.4 mm long, externally with 2-3 tooth on the apex, with sparse moniliform hairs inside. Stamens exserted, filaments dimorphic, inserted at the sinuses of the corolla lobes, the 2 longer stamens with filaments $0.82-1 \mathrm{~mm}$ long, the 2 shorter stamens with subsessile anthers, these oblong, $1-1.2 \times 0.23-0.35 \mathrm{~mm}$. Style exserted, 3-4 mm long, stigma bifid, stigmatic branches $0.3-0.8 \mathrm{~mm}$ long, papillate; nectary disc bipartite. Capsules subsessile (pedicels $0.34-0.44$ mm long), ovoid, $2.2-2.8 \times 2-2.7 \mathrm{~mm}$, glabrous, with 2 septicidally dehiscent valves. Seeds ovoid, $1.5-2 \times 0.7-0.85$ $\mathrm{mm}$, blackish to dark brown; dorsal surface convex, ventral surface with a groove covered by a hyaline strophiole; testa surface reticulo-papillate, cells digitate. The cells have warty irregular projections with a subcircular depression at the apex (Fig. 9 G-I).

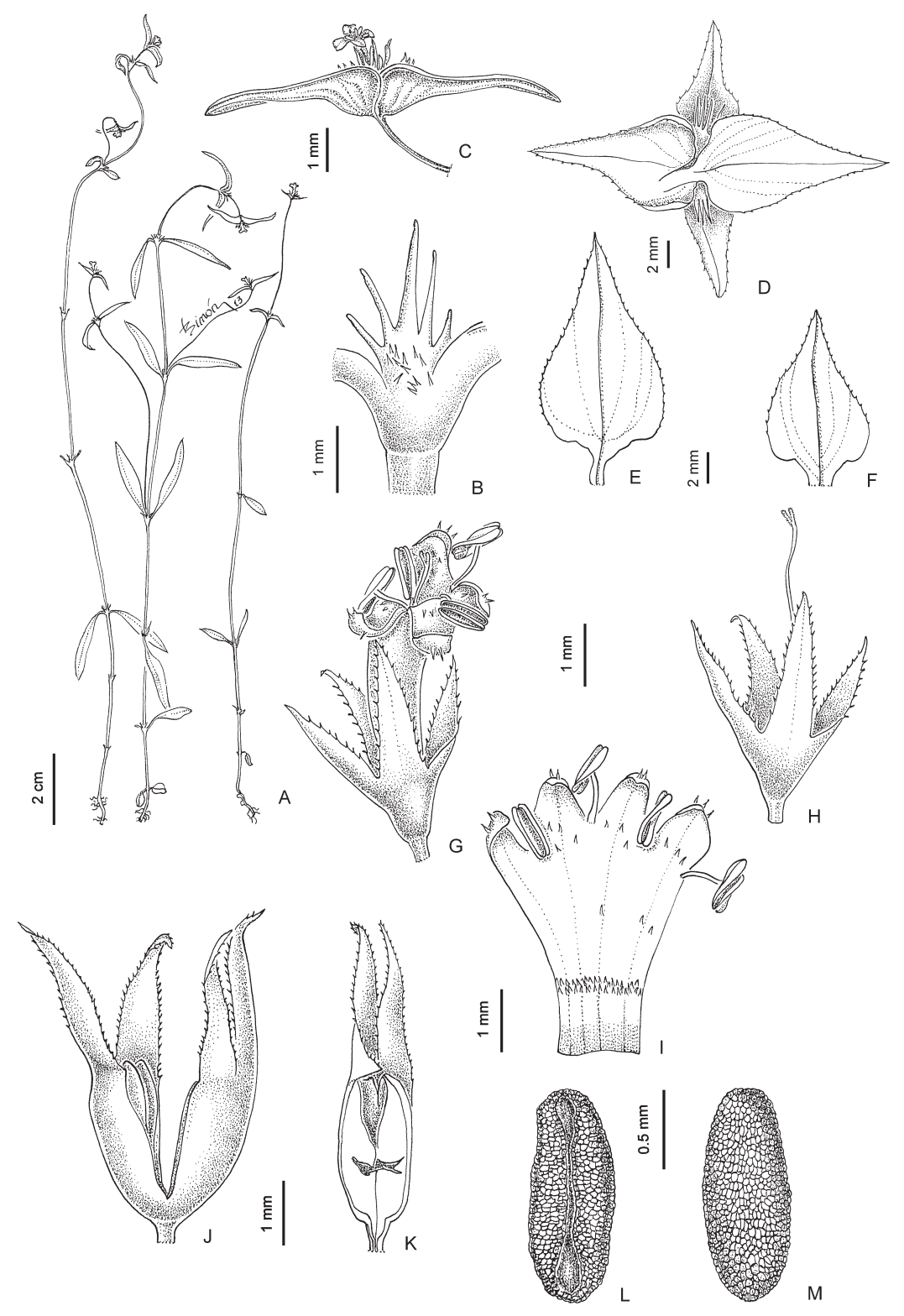

FIGURE 6. Borreria semiamplexicaule E.L. Cabral. A. Habit. B. Stipular sheath. C. Terminal glomerule. D. Abaxial view of glomerule to display inflorescence bracts organization. E. Detail of external bract. F. Detail of internal bract. G. Flower. H. Hypanthium, style and stigma. I. Open corolla. J. Capsule. K. Internal view of mericarp to display septicidal dehiscence. L. Ventral view of seed. M. Dorsal view of seed. (A-C, G-I from Daly D. 1993, D-F from P. L. Viana, F. S. Marino, A. J. Arruda, T. B. Jorge \& P. M. Burkowski 5269, L-M from P. L. Viana, F. S. Marino, A. J. Arruda, T. B. Jorge \& P. M. Burkowski 5257, J-K from A. J. Arruda, F. M. Santos, L. J. Arruda \& T. J. Battituci 928). Illustration by L. Simón. 
Distribution:- In the states of Pará, Goiás, Tocantins, and Mato Grosso, Brazil; at 200-800 m elevation.

Ecology and Phenology:-Flooded grassy fields, campos rupestres on ferrous rocky outcrop, in transitions between low forests to ombrophilous dense forest, near water courses, and also on lateritic soils. Always associated with marsh and wetlands. Flowering and fruiting from February to (probably) June.

Remarks:-This species was originally known from Pará and was recently reported by Delprete (2010) to occur in northern of Tocantins, Brazil. The specimen from Mato Grosso is the first record of this species for this state.

Conservation status:-The extent of occurrence (EOO) is calculated to be $368,675.3 \mathrm{~km}^{2}$, and the area of occupancy (AOO) is estimated at $68.000 \mathrm{~km}^{2}$ (cell size $2 \mathrm{~km}$ ). Therefore, following IUCN red list categories and criteria (IUCN 2012), Borreria semiamplexicaule should be regarded as endangered [EN B2ab(ii, iii, iv)]. The planned mining activities, mainly in the area of Serra dos Carajás (Pará), are the main threat for the species. Moreover, is important to mention that the excessive farming activity in all other locations is also considering a threat for the species. This is presumed due to the soil quality that enables such activities.

Additional specimens examined:-BRASIL. Mato Grosso: Alta Floresta, $9^{\circ} 00^{\prime}$ S, 55 50 $00^{\prime} \mathrm{W}, 246 \mathrm{~m}, 27$ January 2007, D. Sasaki, C. P. Vicenti, L. M. Paz \& J. H. Piva 1426 (INPA); Santa Cruz do Xingu, 94'25” S, 52³6’33” W, 266 m, 3 March 2011, D. C. Zappi, E. Lucas, S. Frisby, W. Milliken, D. R. Silva, C. R. A. Soares, A. F. Forte \& J. H. Piva 3069 (RB); idem, D. C. Zappi, E. Lucas, S. Frisby, W. Milliken, D. R. Silva, C. R. A. Soares, A. F. Forte \& J. H. Piva 3073 (RB). Pará: Marabá, Serra dos Carajás, Serra Norte, 21 May 1969, P. Cavalcante 2083 (MG); idem, 600' S, 50¹8’ W, 700 m, 21 May 1969, P. Cavalcante 2094 (MG, NY); idem, 18 April 1970, P. Cavalcante \& M. Silva 2618 (NY); idem, 20 August 1973, J. M. Pires \& B. C. Passos 13197 (RB); idem, 2 June 1983, N. F. F. Silva, N. A. Rosa, R. P. Bahía \& J. C. Santos 1332 (INPA, MG); idem, N-4, 14 March 1984, A. S. L. da Silva, N. A. Rosa, R. P. Bahia \& M. R. Santos 1762 (INPA, MG, NY); idem, 15 March 1984, A. S. L. da Silva, N. A. Rosa, R. P. Bahia \& M. R. Santos 1816 (MO, NY); idem, 24 April 1985, N. A. Rosa, M. F. da Silva, R. Salamão \& R. P. Bahia 4701 (MG); idem, 4 February 1985, Nascimiento O. C. \& R. P. Bahia 1155 (MG); idem, 3 June 1986, P. M. de Lima Marli \& G. M. Barroso 122 (RB). Conceição do Araguaia: approx. 8³' S, 50¹0' W, 350-620 m, 11 February 1980, T. Plowman, G. Davidse, N. A. Rosa, C. S. Rosário \& M. R. dos Santos 8407 (MO); idem, approx. 8²' S, 504' W, 200 m, 21 February 1980, T. Plowman, G. Davidse, N. A. Rosa, C. S. Rosário \& M. R. dos Santos 8971 (MG, MO). Canaã dos Carajás: N1, Floresta Nacional dos Carajás, 600-800 m, 19 February 2010, L. V. Costa, D. T. Souza, A. J. Arruda, F. Dayrell, F. Costa \& T. Aaimeida 830 (BHCB); idem, L. V. Costa, D. T. Souza, A. J. Arruda, F. Dayrell, F. Costa \& T. Aaimeida 840 (BHCB); S11-A, 6²0’48” S, 50²5’57” W, 711 m, 21 March 2012, A. J. Arruda, P. L. Viana, F. M. Santos, P. B. Mayer \& T. J. Battituci 759 (BHCB, CTES); 6²3’32” S, 50²2'18” W, 20 March 2012, P. M. Burkowski, A. J. Arruda, P. L. Viana, F. M. Santos \& T. J. Battituci 1127 (BHCB); Serra Sul, 6¹9’6” S, 50²7’9” W, 673 m, 21 March 2012, P. M. Burkowski, A. J. Arruda, P. L. Viana, F. M. Santos \& T. J. Battituci 1144 (BHCB); S11B, 6²0’32” S, 50²5'4” W, 724 m, 25 April 2012, A. J. Arruda, F. M. Santos, L. J. Arruda \& T. J. Battituci 1095 (BHCB). Parauapebas: Flona dos Carajás, Corpo A, 6¹9’4” S, 50²6’44” W, 735 m, 21 March 2012, P. L. Viana, F. S. Marino, A. J. Arruda, T. B. Jorge \& P. M. Burkowski 5257 (BHCB, CTES); 6²3’33” S, 50²1’25” W, 730 m, 22 March 2012, P. L. Viana, F. S. Marino, A. J. Arruda, T. B. Jorge \& P. M. Burkowski 5269 (BHCB, CTES); Serra Norte-N7, 69'27” S, 50¹0’12” W, 699 m, 22 March 2012, P. L. Viana, F. S. Marino, A. J. Arruda, T. B. Jorge \& P. M. Burkowski 5306 (BHCB); Serra Norte, 6¹1'8" S, 507'56" W, 23 March 2012, P. M. Burkowski, A. J. Arruda, P. L. Viana, F. M. Santos \& T. J. Battituci 1175 (BHCB); $6^{\circ} 11^{\prime} 8$ " S, 507'56" W, 23 February 2012, P. M. Burkowski, A. J. Arruda, P. L. Viana, F. M. Santos \& T. J. Battituci 1178 (BHCB); 65'43" S, 50¹1'29” W, 24 March 2012, P. M. Burkowski, A. J. Arruda, P. L. Viana, F. M. Santos \& T. J. Battituci 1187 (BHCB); 6¹'52" S, 50¹7’25” W, 688 m, 26 March 2012, P. M. Burkowski, A. J. Arruda, P. L. Viana, F. M. Santos \& T. J. Battituci 1235 (BHCB); 6¹'52” S, 50¹7’25” W, 688 m, 26 March 2012, P. M. Burkowski, A. J. Arruda, P. L. Viana, F. M. Santos \& T. J. Battituci 1239 (BHCB); N1, 600’49” S, 50¹7’51” W, 683 m, 19 April 2012, A. J. Arruda, F. M. Santos, L. J. Arruda \& T. J. Battituci 926 (BHCB); 600’49” S, 50¹7’51” W, 683 m, 19 April 2012, A. J. Arruda, F. M. Santos, L. J. Arruda \& T. J. Battituci 928 (BHCB); N2, 6³'35” S, 50¹4'50” W, 690 m, 19 April 2012, A. J. Arruda, F. M. Santos, L. J. Arruda \& T. J. Battituci 958 (BHCB, CTES); N3, 6²'30" S, 50¹2'28” W, 694 m, 27 March 2012, A. J. Arruda, F. M. Santos, L. J. Arruda \& T. J. Battituci 966 (BHCB); N4-WS, 64'17" S, 50¹1'5” W, 738 m, 23 March 2012, A. J. Arruda, F. M. Santos, L. J. Arruda \& T. J. Battituci 786 (BHCB); 64'17" S, 50¹1'5" W, 738 m, 23 March 2012, A. J. Arruda, F. M. Santos, L. J. Arruda \& T. J. Battituci 790 (BHCB); 66'8" S, 50¹1'9” W, 717 m, 21 April 2012, A. J. Arruda, F. M. Santos, L. J. Arruda \& T. J. Battituci 966 (BHCB); N3, 6¹'44" S, 50¹2'7” W, 656 m, 21 April 2012, A. J. Arruda, F. M. Santos, L. J. Arruda \& T. J. Battituci 1003 (BHCB); N1, 6¹'54.6” S, 50¹7'19.08" W, 25 May 2012, L. V. Costa, A. J. Arruda, M. O. Pivari \& A. O. Santos 967 (BHCB); N6, 67'50”' S, 50¹0'27' W, 697 m, 25 March 2012, A. J. Arruda, F. M. Santos, L. J. Arruda \& T. J. Battituci 846 (BHCB); Santarém, 2०29'7” S, 5448’35” W, 15 April 2005, J. G. Jardim, S. H. N. Monteiro, R. P. Oliveira \& J. B. F. da Silva 4530 (HUEFS). 
Borreria xanthophylla Bremek., Recueil Trav. Bot. Néerl. 31: 306. 1934.—Spermacoce xanthophylla (Bremek.) Govaerts, World Check. Seed Pl. 2: 19. 1996. Type:-SURINAME, Litanie River, Mount Teeboe, 9 August 1904, Versteeg 784 (holotype: U 0007599! [digital image!], isotype: U U0007600 [digital image!], photo MO!). (Figs. 1 J-L, 2 D, 8 A-N, 9 J-L).

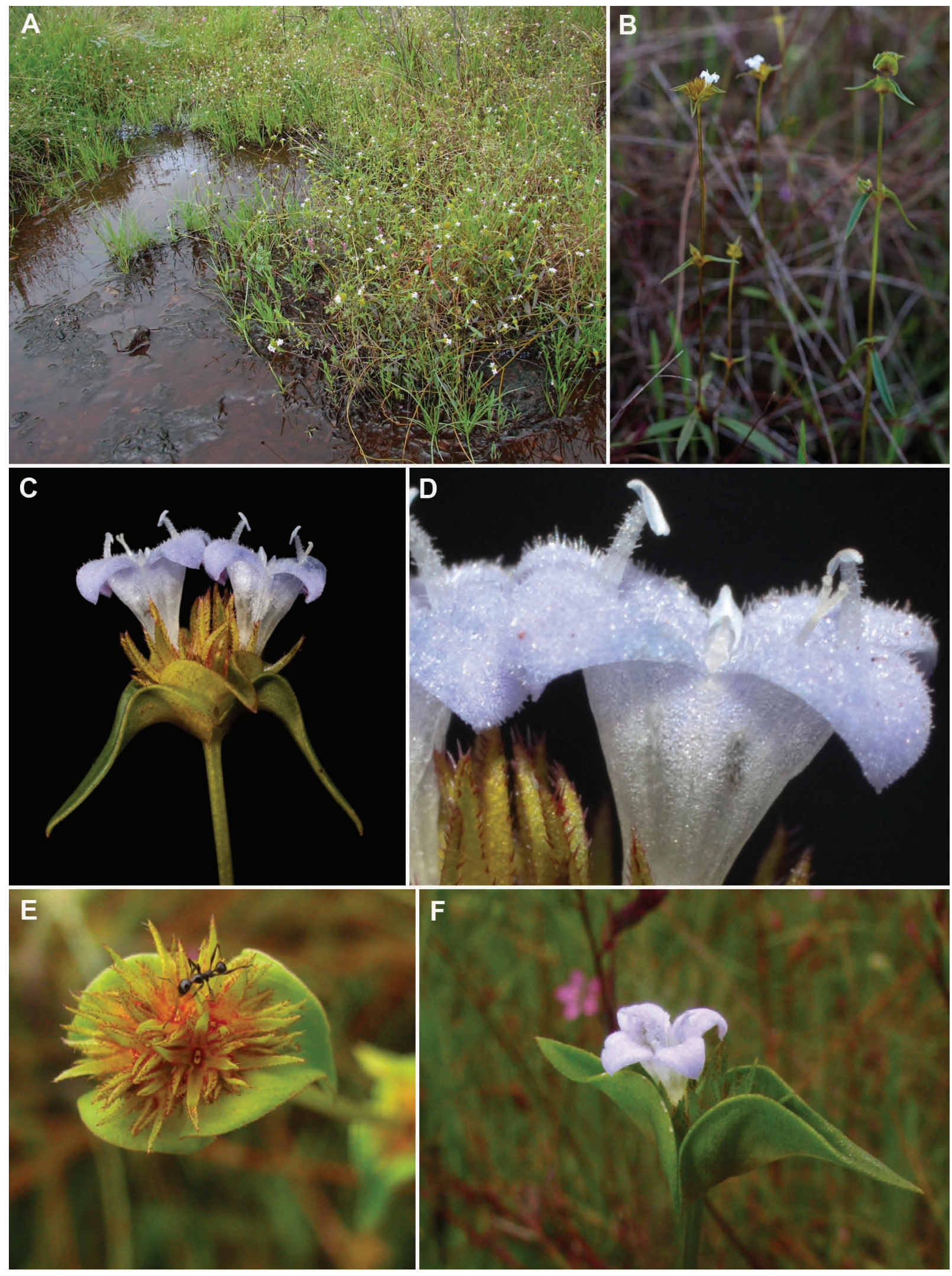

FIGURE 7. Borreria semiamplexicaule E.L. Cabral. A. Flooded grassy fields with outcrop of ferrous rocks. B. Habit. C. Terminal glomerule. D. Detail of flower displaying the staminal organization. E. Terminal glomerule displaying the bipartite nectariferus disc. F. Detail of the sheathing bracts. Photographs A-D by P. L. Viana and E-F by A. J. Arruda. 


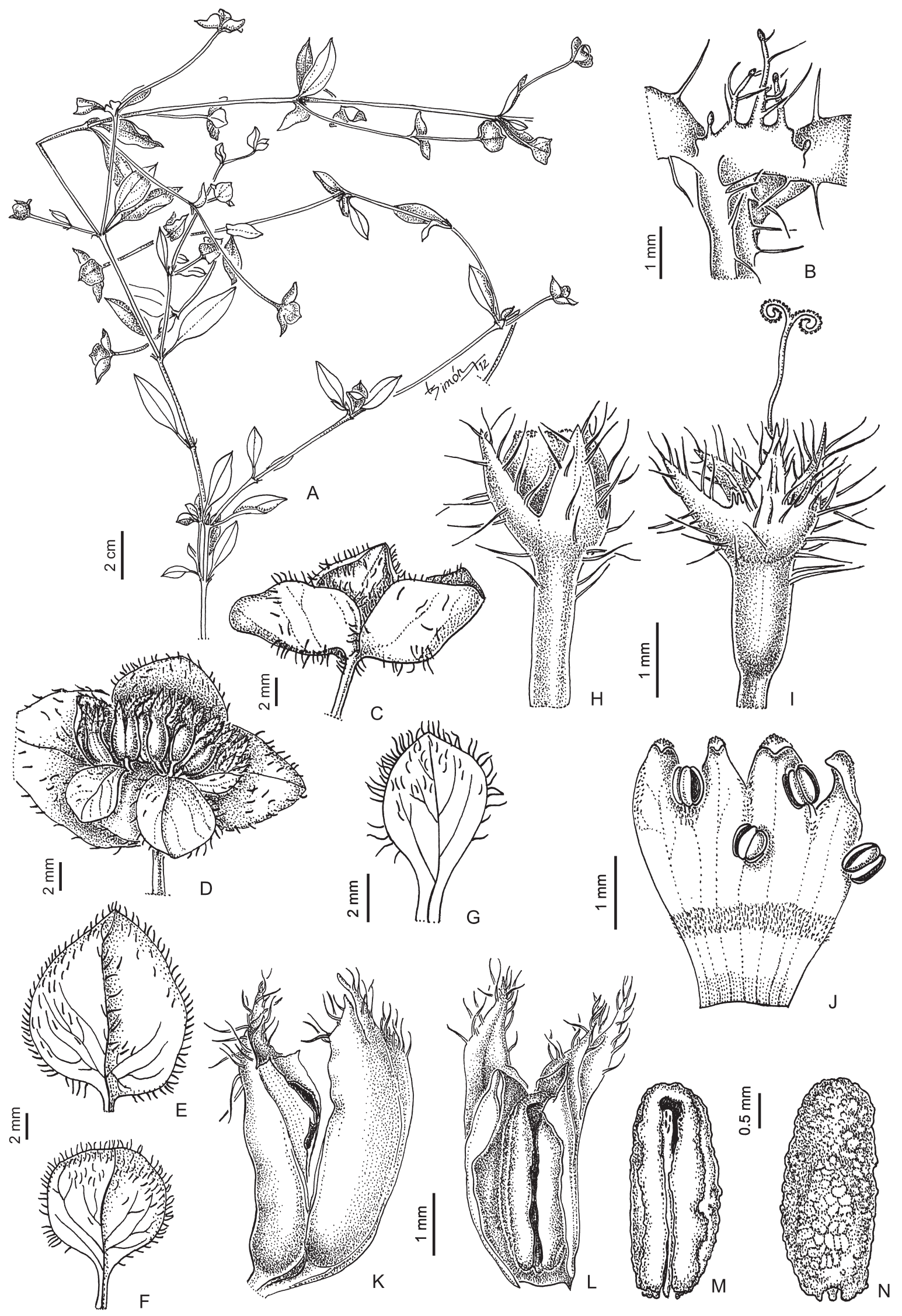

FIGURE 8. Borreria xanthophylla Bremek. A. Habit. B. Stipular sheath. C. Terminal glomerule. D. Detail of terminal glomerule to display fruits. E-F. Detail of external bracts. G. Detail of internal bract. H. Flower bud. I. Hypanthium, style and stigma. J. Open corolla. K. Capsule. L. Internal view of mericarp to display septicidal dehiscence. M. Ventral view of seed. N. Dorsal view of seed. (A-N from $J$. J. de Granville, F. Crozier \& C. Sarthou 15017). Illustration by L. Simón. 
Annual herb, 10-20 cm tall; stems creeping or occasionally erect, 30-60 cm long, 3-5 opposite lateral branches, subquadrangular to tetragonal, winged, glabrous or sometimes hispid at the angles of young branches; internodes 5-9 cm long. Stipular sheaths triangular, 1.25-3 mm long, hispid to villous; setae 3-4, 1-4 mm long, villous, the central ones longer, colleter-tipped. Leaves opposite, pseudo-petiolate; blades ovate, 25-70 $\times 8-20 \mathrm{~mm}$, attenuate at base, acute at apex, chartaceous, margins scabrous, pubescent above and underneath. Inflorescences with 1 terminal and 3-4 axillary glomerules, on principal stems and on opposite lateral branches; glomerules multi-flowered; bracts 6-8, unequal, sheathing and covering all the glomerules, pseudo-petiolate, foliaceous pubescent, the 4 larger external bracts, ovate, $11-16 \times 11-14.5 \mathrm{~mm}$; the 2(-4) smaller internal bracts suborbicular or elliptic, $8-12 \times 5-11 \mathrm{~mm}$. Flowers 4-merous, subsessile (pedicels $0.5-0.6 \mathrm{~mm}$ long). Hypanthium narrowly ovate, $1.5-2 \mathrm{~mm}$ long, with sparse hispid hairs. Calyx lobes triangular, $0.8-1.2 \mathrm{~mm}$ long, united at base in a short tube, $0.55-0.7 \mathrm{~mm}$ long, hispid. Corolla infundibuliform, $3.75-4 \mathrm{~mm}$ long, pale blue-purple; tube $2.2-3 \mathrm{~mm}$ long, glabrous outside, with a ring of moniliform hairs at lower third inside, lobes triangular, $0.7-1 \mathrm{~mm}$ long, with some papillae near the tips outside, with sparse hairs near the anther insertions inside. Stamens 4, unequal, the 2 longer ones slightly exserted, inserted at the corolla lobes sinuses, filaments $0.12-0.2 \mathrm{~mm}$ long, the 2 shorter ones included, inserted at $0.86-1 \mathrm{~mm}$ below the sinuses of the corolla lobes, anthers subsessile, oblong $0.5-0.6 \times 0.44 \mathrm{~mm}$. Style exserted, $3.35 \mathrm{~mm}$ long, stigma bifid, stigmatic branches 1.07 $\mathrm{mm}$ long, stigmatic surface papillate; nectary disc bipartite. Capsules subsessile (pedicels $0.6-1.5 \mathrm{~mm}$ long), oblong, $3.6 \times 1.8-2 \mathrm{~mm}$, hispid at the sepals, with 2 septicidally dehiscent valves. Seeds oblong-ellipsoid, 2.4-3.2 $\times 0.9-1.35$ $\mathrm{mm}$, round at both ends, brown; dorsal surface convex, ventral surface slightly flat with a longitudinal narrow groove forming a straight line from one end to the other; testa surface rugulose-papillate; cells digitate, periclinal walls convex and slightly striate at the round end, anticlinal walls curved or sinuous (Fig. $9 \mathrm{~J}-\mathrm{L}$ ).

Distribution:- Only known from French Guiana and Suriname; at 200-400 m elevation.

Ecology and Phenology:- Edges of shrubby vegetation on rocks, at the edges and on top of granitic inserbergs. Flowering and fruiting from July to December.

Conservation status:- According to the extent of occurrence calculated (EOO: 25,091.008 $\mathrm{km}^{2}$ ) this species could be considered as a threatened species. However, the area of occupancy (AOO) is estimated at $28.000 \mathrm{~km}^{2}$ (cell sized 2 $\mathrm{km}$ ) in a severely fragmented area; besides, the species is known from nine collections from French Guiana. Therefore, following IUCN criteria (IUCN 2012), the species can be referred to as an endangered (EN B2ab(ii, iii, iv).

Additional specimens examined:-FRENCH GUIANA. Savane du Rocher, 15 December 1914, R. Benoist 1507 (P); Frontière Guyane-Brésil, 13 April 1983, C. Feuillet 1011 (MO); Pic du Grand Croissant, Basin de L'Armantabo, $3^{\circ} 31^{\prime} \mathrm{N}, 52^{\circ} 22^{\prime} \mathrm{W}, 150 \mathrm{~m}, 14$ April 1993, J. J. de Granville 11748 (MO); Montagne Emérillons, Région des Emérillons, $3^{\circ} 15^{\prime}$ N, 53도 ' W, 200 m, 17 May 1995, J. J. de Granville \& G. Cremers 12942 (MO, NY); Mitaraka Sud, sommet inselberg, $2^{\circ} 16^{\prime}$ N, 5431' W, 660 m, 5 March 2001, C. Sarthou 839 (MO, NY); Monts d'Arawa: zone de la savaneroche centrale, $2^{\circ} 49^{\prime}$ N, 5322' W, 220 m, 4 July 2002, J. J. de Granville, F. Crozier \& C. Sarthou 15017 (BR, MO, NY); idem, “savane-roche" [inselberg] central, $2^{\circ} 49^{\prime}$ N, 532' W, 200 m, 13 July 2002, J. J. de Granville, F. Crozier $\&$ C. Sarthou 15234 (MO); Mont Saint-Marcel, zone centre-est du massif, $2^{\circ} 23^{\prime}$ N, 530’ ' W, 420 m, 19 July 2002 , J. J. de Granville, L. Aliker \& C. Sarthou 15349 (MO); inserbergs du haut Marouini-A: Inselberg de la D.Z., 254' N,

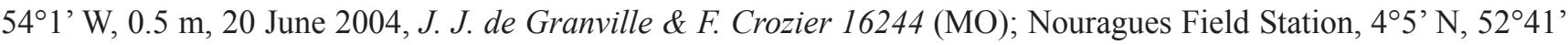
W, 120 m, 13 August 2004, S. A. Mori, T. Lobova, N. Pitcairn, C. Geiselman \& B. Vlásákova 25775 (MO).

\section{Discussion}

The new species Borreria heteranthera and the other three species presented in this study display a peculiar staminal arrangement. This phenomenon represents an unusual and so far the only reported case in Rubiaceae showing an intrafloral variation of insertion/length of stamens in homostylous flowers. As we explained above, this feature, first described by Aublet (1775: 60), was little used in the taxonomic descriptions of this species group. For this reason, we propose the staminal organization as a diagnostic feature in the Amazonian species of Borreria subsection Latifoliae. Indeed, we consider this feature very important, because the genus Borreria is entirely homostylous. An analogous case occurs in the Neotropical genus Ferdinandusa Pohl (1831: 8). The species of this genus as same Borreria heteranthera and $B$. semiamplexicaule display an intrafloral variation of the filaments length. Ferdinandusa is a homostylous genus and has inserted or exserted stamens, with subequal or filaments with variable length (Delprete 2010, 2012). However, this genus does not present a staminal arrangement in pairs similar as the species of Borreria cited, and also has protandrous flowers. Other similar case occurs in the endemic Madagascan genus Amphistemon Groeninckx (2010: 
450). This genus is the only in Spermacoceae with anthers positioned at two levels in the corolla tube. However, it differs from the four species presented here by having heterostylous flowers (Groeninckx et al. 2010).

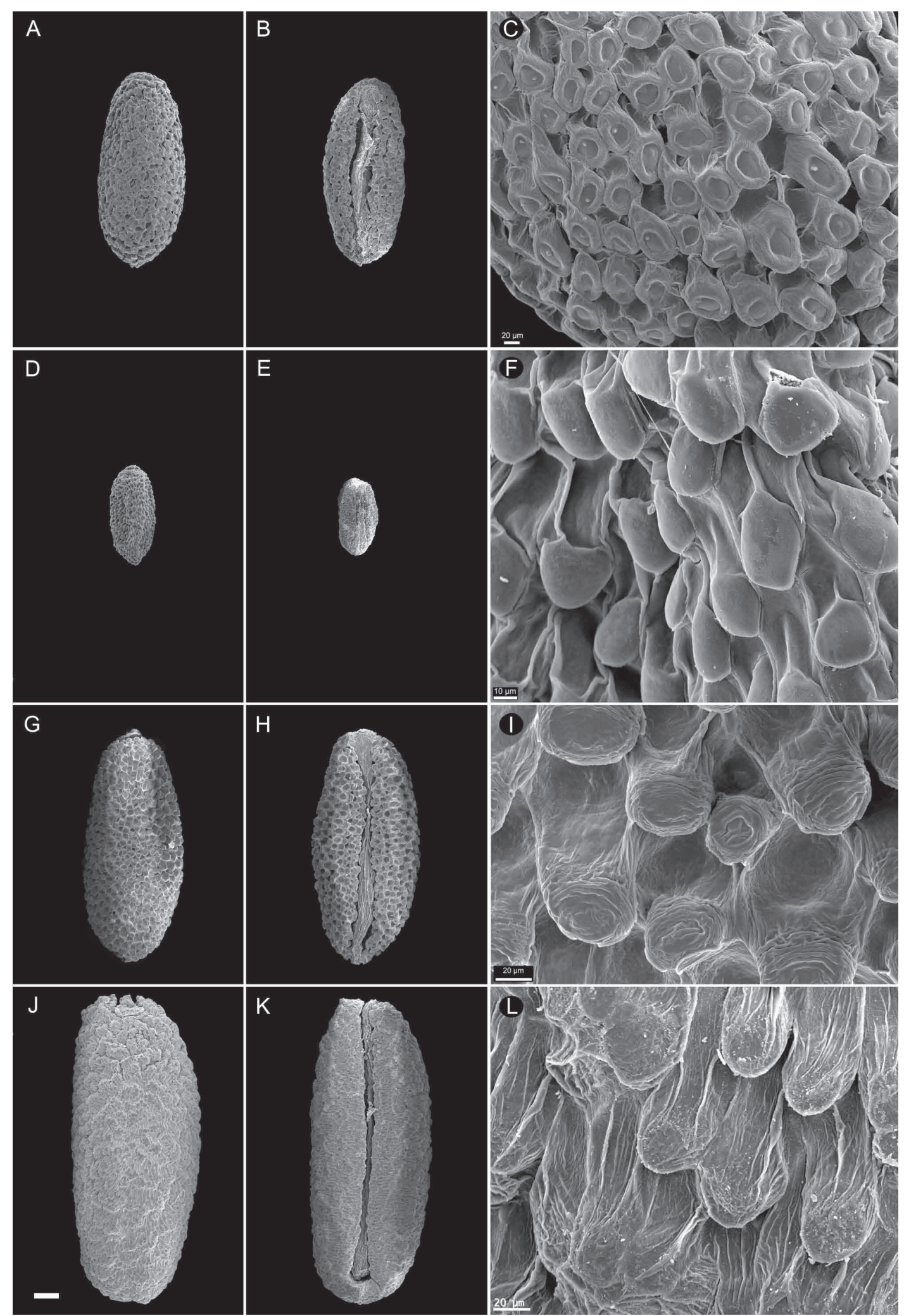

FIGURE 9. Scanning electron microscopy (SEM) micrographs of seeds. Borreria heteranthera (A-C from A. J. Arruda, P. L. Viana, F. M. Santos, P. B. Mayer, T. J. Battituci \& L. J. Arruda 826). A. Dorsal view. B. Ventral view. C. Detail of the reticulo-papillate testa and digitate cells. Borreria hispida (D-F from W. J. Burchell 8675). D. Dorsal view. E. Ventral view. F. Detail of the papillate testa surface and digitate cells. Borreria semiamplexicaule (G-I from A. J. Arruda, F. M. Santos, L. J. Arruda \& T. J. Battituci 1095). G. Dorsal view. H. Ventral view. I. Detail of the reticulo-papillate testa. Borreria xanthophylla (J-L from J. J. de Granville, F. Crozier \& C. Sarthou 15017). J. Dorsal view. K. Ventral view. L. Detail of the rugulate-papillate testa and digitate cells. Scale bar $200 \mu \mathrm{m}$. 
Borreria subsection Latifoliae consists of ca. 12 South American species with the inclusion of Borreria heteranthera and $B$. xanthophylla. The four species here analyzed present a relatively uniform seed morphology. The seeds are brown, ovoid (Borreria heteranthera and B. semiamplexicaule) or oblong and round at both ends ( $B$. hispida and B. xanthophylla), and similar sizes (1.5-2.4 x 0.6-1.35). Except in B. hispida, which has the smallest seeds $(0.6-0.8 \times 0.3-0.4 \mathrm{~mm})$ in the group. The ventral surface is flat and presents a \pm deep groove, covered by a hyaline strophiole and raphids. In $B$. hispida, the strophiole exceeds the apex of the seeds. The testa surface is reticulo-papillate (B. heteranthera and B. semiamplexicaule), rugulose-papillate (B. xanthophylla), or simply papillate (B. hispida). According to these observations, we concluded that the seed morphology is a uniform feature for this species group. Although this is not an interspecific diagnostic feature, it can be used to characterize these species. The pollen morphology is also uniform among them. The grains are zonocolpate (8-11), oblate-spheroidal to prolatespheroidal $(\mathrm{P} / \mathrm{E}=0.84-1.06)$, medium-sized $(\mathrm{P}=31-45 \mu \mathrm{m} ; \mathrm{E}=33-45 \mu \mathrm{m})$, and with a circular polar outline. The colpi are medium-sized $(\mathrm{LC} / \mathrm{P}=(23-) 26-38)$ and slit-like. The endoaperture is a ring-shaped endocingulum lying in the ecuatorial plane ranging (4-)7-10 $\mu \mathrm{m}$ long at the colpus zone. In this area, the endocingulum appears as a round end at SEM. However, broken grains observed at SEM confirmed that is a continuous endoaperture, with or without mesocolpium extensions. The tectum is uniformly spinulate and present irregular perforations ranging $0.16-0.4 \mu \mathrm{m}$ in diameter. The nanospines are $0.25-0.5 \mu \mathrm{m}$ long. The inner nexine surface is finely granular and may present narrow and superficial endocracks or broad and deep irregular ones. The above features correspond with the pollen type 2 described by Pire (1996) and Dessein et al. (2002). This pollen type was originally characterized by its 8-9-colporate and medium-sized grains with medium colpi, tectum with \pm large perforations, and uniformly spinulate. Pire (1996) linked this pollen type to some species of Borreria subsection Latifoliae (Borreria balansae Standley (1931: 389), B. latifolia (Aublet 1775: 55-57) Schumann (1888: 61), B. nana Standley, B. poaya (Saint Hilaire 1824: XII) Candolle (1830: 549), and B. wurdackii Steyermark (1972: 812). However, we found some differences between the species cited above (Sobrado \& Cabral, in press), the four species treated in the present study, and the Pire (1996) and Dessein et $a l$. (2002) proposals. The inner surface nexine and the endocingulum analyzed allow us to re-describe the pollen type 2 sensu Pire (1996). Moreover, Borreria hispida and B. semiamplexicaule were classified initially as type 3-subtype $3 b$ (Pire 1996). This type is recognized by its 6-9(-10-12)-orthocolporate or loxocolporate grains, with short and narrow colpi, oblate-spheroidal or less frequent protale-spheroidal and suboblate, with small or medium size, and perforate tectum, uniformly spinulate. According to the arrangement and length of the apertures and the presence of an endocingulum we transfer these two species from the pollen type 3-b to the type 2 pollen group.

\section{Acknowledgements}

We are grateful to Alexandre Salino (BHCB) for loans of herbarium specimens, and to Roxali Bijmoer (L, Collections Manager) for digital images of the Borreria xantophylla type. Also, we thank Roberto M. Salas for the information obtained from the M herbarium, and Laila M. Miguel for the comments suggestions. We also thank to Laura Simón for preparing the line drawings and to Pedro L. Viana and André J. Arruda for the photographs. The first author thanks to Consejo Nacional de Investigaciones Científicas y Tecnológicas (CONICET), for the grants awarded that support this work. We thanks to two anonymous reviewers and the editor also for suggestions on the manuscript.

\section{References}

Adams, C.D. (1993) Spermacoce. In: Burger, W. \& Taylor, C.M. (Eds.) Rubiaceae. Flora Costaricensis. Fieldiana, Botany, New series 33 : 313-320.

Adams, C.D. \& Taylor, C.M. (2012) Spermacoce- Rubiaceae. In: Davidse, G.M., Sousa, S., M., Knapp, S., Chiang C, F. \& Ulloa Ulloa, C. (Eds.) Flora Mesoamericana, Volume 4, Parte 2. Universidad Nacional Autónoma de México, Missouri Botanical Garden, The Natural History Museum (London), Missouri Botanical Garden, St. Louis, pp. 275-282.

Aublet, J.B.C.F. (1775) Spermacoce. Histoire des Plantes de la Guiane Françoise. P.-F. Didot, London \& Paris, pp. 55-61, pl. 19-22.

Bachman, S., Moat, J., Hill, A.W., de la Torre, J. \& Scott, B. (2011) Supporting Red List threat assessments with GeoCAT: geospatial conservation assessment tool. In: Smith, V. \& Penev, L. (Eds.) e-Infrastructures for data publishing in biodiversity science. ZooKeys 150: 117-126. Available from: http://geocat.kew.org (accessed 9 December 2014).

Bacigalupo, N.M. \& Cabral, E.L. (1996) Infrageneric classification of Borreria (Rubiaceae-Spermacoceae) on the basis of American 
species. In: Robbrecht, E., Puff, C. \& Smets, E. (Eds.) 2nd Int. Rubiaceae Conf. Meise (1995). Opera Botanica Belgica 7: 297308.

Bacigalupo, N.M. \& Cabral, E.L. (2007) Tribu Spermacoceae. In: Wanderley, M., Shepherd, G., Melhem, T. \& Giulietti, A.M. (Eds.) Flora Fanerogâmica do Estado de São Paulo, volume 5. Instituto de Botânica, São Paulo, pp. 276-285.

Bacigalupo, N.M., Cabral, E.L. \& Cabaña Fader, A.A. (2010) Spermacoce spiralis, a new name for Diodia assurgens (Rubiaceae). Plant Ecology and Evolution 143: 98-102.

Bremekamp, C.E.B. (1934) Notes on the Rubiaceae of Suriname. Recueil des Travaux Botaniques Néerlandais 31: 248-308.

Cabral, E.L. (1996) Cuatro especies nuevas de Borreria (Rubiaceae) para la Flora de Brasil. Bonplandia 9 (1-2): 37-41.

Cabral, E.L., Cabaña Fader, A.A. \& Bacigalupo, N.M. (2010) A new species of Spermacoce s. str. (Spermacoceae, Rubiaceae) from Eastern Brazil. Plant Ecology and Evolution 143: 233-238.

Cabral, E.L., Miguel, L.M. \& Salas, R.M. (2011) Dos especies nuevas de Borreria (Rubiaceae), sinopsis y clave de las especies para Bahia, Brasil. Acta Botánica Brasilica 25: 255-276.

Cabral, E.L., Miguel, L.M. \& Salas, R.M. (2012a) Comentarios sobre la identidad taxonómica de Borreria valens (Rubiaceae) y descripción de Borreria orientalis, nueva especie de Argentina, Brasil y Paraguay. Boletín de la Sociedad Argentina de Botánica 47: 427-434.

Cabral, E.L., Miguel, L.M. \& Viana, P.L. (2012b) Two new species of Borreria (Rubiaceae) from Brazil, with new distributional records for Pará State and a key to species with transversally sulcate seeds. Annales Botanici Fennici 49: 209-215.

Cabral, E.L. \& Salas, R.M. (2013) Borreria. In: Lista de Espécies da Flora do Brasil. Jardim Botânico do Rio de Janeiro. Available from: http://floradobrasil.jbrj.gov.br/jabot/floradobrasil/FB20690.

Candolle de, A.P. (1830) Spermacoceae. Prodromus Volume 4. Treuttel \& Würtz, Paris, pp. 538-578.

Cuvier, F.G. (1827) Spermacoce alata. Dictionnaire des Sciences Naturelles, Volume 50. In: Levrault, F.G. (Ed.) Strasbourg, Paris, pp. $115-116$

Delprete, P.G. (2007) New combination and new synonymies in the genus Spermacoce (Rubiaceae) for the Flora of Goiás and Tocantins (Brazil) and the Flora of The Guianas. Journal of the Botanical Research Institute of Texas 1: 1023-1030.

Delprete, P.G. (2010) Spermacoce. In: Rizzo, J.Â. (Ed.) Flora dos Estados de Goiás e Tocantins-Coleção Rizzo, Volume 40, Rubiaceae, Parte 3: Gêneros $S$-W. Universidade Federal de Goiás and Institut de Recherche pour le Développment, Goiânia, pp. 1153-1309.

Delprete, P.G. (2010) Ferdinandusa. In: Rizzo, J.Â. (Ed.) Flora dos Estados de Goiás e Tocantins-Coleção Rizzo, Volume 40, Rubiaceae, Parte 1: Gêneros A-H. Universidade Federal de Goiás and Institut de Recherche pour le Développment, Goiânia, pp. $422-440$.

Delprete, P.G. (2012) Ferdinandusa. In: Cavalcanti, T.B. \& Dias, E.B.A. (Ed.) Flora do Distrito Federal, Volume 10. Embrapa, Brasília, Distrito Federal, pp. 92-96.

Delprete, P.G. \& Cortés, R. (2006) A synopsis of the Rubiaceae of the states of Mato Grosso do Sul, central-western Brazil, with a key to genera, and preliminary species list. Revista de Biologia Neotropical 3: 13-96.

Delprete, P.G., Smith, L.B. \& Klein, R.B. (2005) Rubiáceas, Volume 2-Géneros de H-T: 20. Gardênia to 46. Tocoyena. In: Reis, A. (Ed.) Flora Ilustrada Catarinenese. Herbário Barbosa Rodrigues, Itajaí, Brasil, pp. 702-776.

Dessein, S., Huysmans, S., Robbrecht, E. \& Smets, E. (2002) Pollen of African Spermacoce species (Rubiaceae). Morphology and evolutionary aspects. Grana 41: 69-89.

Dessein, S. (2003) Systematic studies in the Spermacoceae (Rubiaceae). Ph. D. Thesis. Institute of Botany and Microbiology, Laboratory of Plant Systematics, Leuven, Belgium, 403 pp.

Dessein, S., Jansen, S., Robbrecht, E. \& Smets, E. (2003a) A new species of Spermacoce (Rubiaceae) from the Manika high plateau (Katanga; R. D. Congo). Nordic Journal of Botany 22: 513-523.

Dessein, S., Ntore, S., Robbretch, E. \& Smets, E. (2003b) Pollen and seeds reveal that Spermacoce thymoidea s.l. (African Rubiaceae, Spermacoceae) represents three endemic or disjunct species from the Zambezian high plateaus. Systematic Botany 28: 130-144.

Don, G. (1834) CLXXXV-Borreria, 25. Borreria alata. A General History of the Dichlamydeous Plants, Volume III. Gilbert \& Rivington, London, pp. 613-614.

Erdtman, O.G.E. (1966) Pollen Morphology and Plant Taxonomy Angiosperms. An introduction to Palynology-I. Hafner Publishing Company, New York and London, 557 pp.

Govaerts, R.H.A. (1996) Spermacoce neohispida. World Checklist of Seeds Plantas 2 (1): 18.

Groeninckx, I., Dessein, S., Ochoterena, H., Persson, C., Motley, T.J., Kårehed, J., Bremer, B., Huysmans, S. \& Smets, E. (2009) Phylogeny on the herbaceous tribe Spermacoceae (Rubiaceae) based on plastid DNA data. Annals of the Missouri Botanical Garden 96: 109132 .

Groeninckx, I., De Block, P., Robbrecht, E., Smets, E.E. \& Dessein, S. (2010) Amphistemon and Tamnoldenlandia, two genera of Rubiaceae (Spermacoceae) endemic to Madagascar. Botanical Journal on the Linnean Society 163: 447-472.

Harwood, R. \& Dessein, S. (2005) Australian Spermacoce (Rubiaceae: Spermacoceae). I. Northern Territory. Australian Systematic Botany 18: 297-365.

Hassler, E. (1915) Borreria sectio Pseudodiodia. Ex herbario Hassleriano: Novitates paraguarienses XX. In: Fedde, F. (Ed.) Repertorium Specierum Novarum Regni Vegetabilis, Fasciculus XIV (1914/16). Berlin, pp. 166-167. 
IUCN (2012) IUCN Red List Categories and Criteria: Version 3.1. Second edition. Gland, Switzerland and Cambridge, UK: IUCN. iv + $32 \mathrm{pp}$.

Kårehed, J., Groeninckx, I., Dessein, S., Motley, T.J. \& Bremer, B. (2008) The phylogenetic utility of chloroplast and nuclear DNA markers and the phylogeny of the Rubiaceae tribe Spermacoceae. Molecular Phylogenetics and Evolution 49: 843-866.

Lamarck, J.B.P.M. \& Poiret, J.L.M. (1783) Encyclopedie Methodique: Botanique. [Suppl. 7]. Liège: Panckoucke; Plomteux, Paris, 315 pp.

Linnaeus, C. (1753) Species Plantarum. Laurentius Salvius, Stockholm, 1200 pp.

Martius, C.F.P. \& Zuccarini, J.G. (1824) Psyllocarpus. In: Kunze, G. (Ed.) Ankiindigung der Fortsetzung eines Werkes iiber brasilianische Pflanzen, Flora 7 (1) supplement (4). Königl botanischen Gesellschaft, Regensburg, pp. 130-131.

Meyer, G.F.W. (1818) Borreria. Primitiae Florae Essequeboensis adjectis descriptionibus centum circiter stirpium novarum, observationibusque criticis. Sumptibus H. Dieterich, Gottingae, pp. 79-81.

Miguel, L.M. \& Cabral, E.L. (2013) Borreria krapocarmeniana, a new cryptic species recovered through taxonomic analyses of Borreria scabiosoides and Borreria linoides (Spermacoceae, Rubiaceae). Systematic Botany 38 (3): 769-781.

Pire, S.M. (1996) Palynological study of American species of Borreria (Rubiaceae-Spermacoceae). In: Robbrecht, E., Puff, C. \& Smets, E. (Eds.) 2nd Int. Rubiaceae Conf. Meise (1995). Opera Botanica Belgica 7: 413-423.

Pohl, J.B.E. (1831) Ferdinandusa. Plantarum Brasiliae Icones et Descriptiones 2: 8-9.

Punt, W., Blackmore, S., Nilsson, S. \& Le Thomas, A. (2007) Glossary of pollen and spore terminology. Review of Palaeobotany and Palynology 143: 1-81.

Saint-Hilaire de, A.M. (1824) Spermacoce poaya. Plantes Usuelles des Brasiliens. Grimbert Libraire, Paris, № XII.

Salas, R.M., Soto, D. \& Cabral, E.L. (2011) Dos especies nuevas de Borreria (Rubiaceae), un nuevo registro de Declieuxia y observaciones taxonómicas. Brittonia 63: 286-294.

Schumann, K.M. (1888) Trib. VIII Spermacoceae. In: Martius, C.F.P., Eichler, A.G. \& Urban, I. (Ed.) Flora Brasiliensis vol. 6 , part 5. Monachii \& Lipsiae, F. Fleischer, pp. 5-102, tab. 68-85.

Secco, R.S. \& Mesquita, A.L. (1983) Notas sobre vegetação de canga da Serra Norte-I. Boletim do Museu Paraense Emílio Goeldi, série Botânica 59: 1-13.

Silva da, M.F.F., Secco, R.S. \& Lobo, M.G.A. (1996) Aspectos ecológicos da vegetação rupestre da Serra dos Carajás, Estado do Pará, Brasil. Acta Amazonica 26 (1-2): 17-44.

Sivarajan, V.V., Nair Vasudevan, R. \& Ahmed Kunju, T.U. (1987) Genus Spermacoce Linn. (Rubiaceae) in India. Proceedings of the Indian Academy of Science Plant Sciences 97: 347-358.

Standley, P.C. (1931) Borreria balansae. Publications of the Field Museum of Natural History, Botanical Series 8: 389.

Standley, P.C. (1940) Borreria nana. Publications of the Field Museum of Natural History, Botanical Series 22: 110.

Stearn, W.T. (1986) Botanical Latin. David \& Charles Publishers, London, 557 pp.

Steyermark, J.A. (1972) Borreria. In: Maguire, B. and Collaborators (Eds.) The Botany of the Guayana Highland-Part IX. Memoirs of the New York Botanical Garden 23: 805-831.

Thiers, B. (2013) Index Herbariorum: A global directory of public herbaria and associated staff. New York Botanical Garden's Virtual Herbarium. Available from: http://sweetgum.nybg.org/ih/.

Verdcourt, B. (1976) Rubiaceae. Tribe 8. Hedyotideae. In: Polhill, R.M. (Ed.) Flora of Tropical East Africa-part 1. Crown Agents for Oversea Governments and Administrations, London, pp. 177-315.

Wikström, N., Neupane, S., Kårehed, J., Motley, T.J. \& Bremer, B. (2013) Phylogeny of Hedyotis L. (Rubiaceae: Spermacoceae): Redefining a complex Asian-Pacific assemblage. Taxon 62: 357-374.

Willdenow, C.L.V. (1798) Spermacoce alata. Species Plantarum. Editio Quarta. Berolini, Berlin, 569 pp.

Zuccarini, J.G. (1827) Mitracarpus. Mantissa Volume 3. Cottae, Stuttgart, pp. 210-319. 